\title{
The Concept of "Real Interest" and Other Aspects of Co-operation through Regional Fisheries Management Mechanisms
}

\author{
Erik Jaap Molenaar* \\ Netherlands Institute for the Law of the Sea (NILOS). \\ Utrecht University, The Netherlands
}

\begin{abstract}
The concept of "real interest" is incorporated in Article 8(3) of the 1995 Fish Stocks Agreement as a condition that states (parties) must fulfil before they can participate in a regional fisheries management mechanism (RFMM). As the 1995 Agreement does not define the concept, this article examines its possible meaning. A general discussion on the need for, and duties of, co-operation in the conservation and management of transboundary stocks provides the context in which the concept of "real interest" is placed. Arguments justifying the use of the concept of "real interest" as a bar to participation in RFMMs are examined in addition to the concept's potential use in dealing with flag states with bad performance records. Ample attention is given to the practice of states cooperating in existing RFMMs and in negotiation processes aimed at establishing RFMMs, as this will play a decisive role in giving effective meaning to the concept.
\end{abstract}

\section{Introduction}

The extension of coastal state jurisdiction over marine living resources which was brought about by state practice and ultimately recognised in the United Nations Convention on the Law of the Sea (LOS Convention), ${ }^{1}$ meant a substantial shift in the balance of interests between coastal and flag states. Coastal states had gained sovereignty or sovereign rights over all living marine resources within 200

* The author would like to acknowledge the generous assistance of, and/or comments by, $S$. Asmundsson, H. Dotinga, J. Harford, T.L. McDorman, D. Miller, B. Oelofsen, A.G. Oude Elferink, C. Paz, A. Serdy and F. Wieland on an earlier version of this article. The author naturally remains responsible for the current text.

1 Montego Bay, 10 December 1982, in force 16 November 1994, (1982) 21 ILM 1245. As of 1 September 2000 , there were 133 parties to the LOS Convention.

THE INTERNATIONAL JOURNAL OF MARINE AND COASTAL LAW, Vol 15, No 4

(C) Kluwer Law International, 2000 
nautical miles off their coasts. ${ }^{2}$ Expectations were high that the main benefactors, coastal states, would manage their resources wisely. Nevertheless, consistent emphasis was placed on the fact that duties of co-operation were an essential ingredient of this new jurisdictional balance. This emphasis was also called for as inter-state co-operation prior to the adoption of the LOS Convention was mainly concerned with high seas resources and therefore had to adjust to the new balance of power and the changed geographical configuration.

It is common knowledge that this redistribution in the balance of interests has in general failed to prevent marine living resources from coming under continuously increasing pressure; so much so that citing from authoritative sources that underscore this view has become superfluous. It has in fact become more informative to identify fisheries that are reasonably well managed and not in danger of collapsing. ${ }^{3}$ In the $1990 \mathrm{~s}$, the need to modify or enhance the effectiveness of this jurisdictional redistribution led to a series of initiatives at the international level. ${ }^{4}$ Two elements of these initiatives stand out in particular: (1) reinforcing flag state performance and (2) promoting co-operation, especially at the regional level. This article focuses in particular on the latter element, viz. the growing support for regional co-operation in the management of marine living resources. ${ }^{5}$

The article begins by discussing the need for co-operation, both from the perspective of common sense and of legal duty. Some attention is subsequently devoted to negotiation, which is commonly an initial stage of co-operation. The article then focuses on regional co-operation through regional fisheries management mechanisms (RFMMs). This acronym is used as an overarching term inspired by the distinction between organisations and arrangements in the 1995 Fish Stocks Agreement. ${ }^{6}$ After briefly considering the issue of the spatial

2 More correctly: from the baselines for the measurement of the territorial sea (see Arts 5-14 of the LOS Convention). Sovereign rights also exist over sedentary species of the legal continental shelf, which can extend beyond 200 nautical miles (see Arts 56(3), 76 and 77(4) of the LOS Convention and note 16 below).

3 For recent information on global fisheries, see The State of the World Fisheries and Aquaculture, 1998 (Rome, FAO, 1999).

4 For an overview, see E. Hey, "Global Fisheries Regulations in the First Half of the 1990s", (1996) 11 International Journal of Marine and Coastal Law 459-490.

5 For the purpose of this article, management is regarded as comprising both conservation and use (see the definitions of "conservation" and "management" used by S.N. Nandan and S. Rosenne (volume eds) and N.R. Grandy (assistant ed.), United Nations Convention on the Law of the Sea 1982, A Commentary (The Hague, London, Boston, Martinus Nijhoff Publishers, 1995), vol. III, p. 29). The objective of sustainability laid down in Art. 2 of the 1995 Fish Stocks Agreement (see note 6 below) is used instead of "proper conservation" (Art. 61(2) of the LOS Convention). Overarching objectives used in the FAO Code of Conduct for Responsible Fisheries (Rome, 31 October 1995) (www.fao.org/WAICENT/FAOINFO/FISHERY/fishery.htm) include: "responsible fisheries" (Art. 2(c)), "effective conservation and management" (section 6.1), "sustainable utilization" (sections 6.3 and 7.2.1) and "long-term conservation and sustainable use" (section 7.1.1).

6 Agreement for the Implementation of the Provisions of the United Nations Convention on the Law of the Sea of 10 December 1982 Relating to the Conservation and Management of Straddling Fish Stocks and Highly Migratory Fish Stocks (New York, 4 August 1995, not in 
scope of an RFMM's regulatory area, the article comes to its main emphasis: rights and duties of participation in an RFMM in the light of the concept of "real interest". This concept is incorporated in Article 8(3) of the 1995 Fish Stocks Agreement as a condition that states must fulfil before they can participate in an RFMM. As the Agreement does not define the concept, this article examines its possible meaning. A very significant role in giving effective meaning to the concept is reserved for the practice of states co-operating in existing RFMMs and in negotiation processes aimed at establishing RFMMs. Such state practice is discussed below.

As the absence of a definition of the concept of real interest may very well lead to disputes over its interpretation or application, the discussion at pp. 000-000 below deals with dispute settlement. The emphasis here is mainly on the relationship between dispute settlement procedures within RFMMs and those in Part XV of the LOS Convention. The text below finally summarises the findings in some conclusions.

\section{Co-operation: Duty and Common Sense}

The core of the problems in global marine catch fisheries is caused by the fundamental characteristics of marine fish, namely that they are a common property and renewable natural resource incapable of being spatially confined. ${ }^{7}$ Failure to regulate will therefore inevitably lead to over-exploitation and economic inefficiency and, ultimately, conflict at the domestic and/or the international level. As many fish stocks are not confined to single regulatory

cont.

force; UN Law of the Sea Bulletin 29 (1995), p. 25; at 1 September 2000 there were 26 states parties (30 needed)). Art. 1(1)(d) of the Agreement defines "arrangement" as: "a cooperative mechanism established in accordance with the Convention and this Agreement by two or more States for the purpose, inter alia, of establishing conservation and management measures in a subregion or region for one or more straddling fish stocks or highly migratory fish stocks". An arrangement could, for instance, be a series of conferences or instruments, or a designated committee. RFMMs comprise regional fisheries organisations like the Northwest Atlantic Fisheries Organization (NAFO) but not arrangements like the South Pacific Forum Fisheries Agency (FFA), as the latter does not have the competence to establish binding conservation and management measures. The FAO commonly uses the term "regional fishery bodies" (RFBs), defined as "a mechanism through which three or more States or international organisations that are parties to an international fishery agreement or arrangement collaboratively engage each other in multilateral management of fishery affairs related to transboundary, straddling, highly or high seas migratory stocks, through the collection and provision of scientific information and data, serving as technical and policy forum, or taking decisions pertaining to the development and conservation, management and responsible utilisation of the resources" (e.g. FAO, Major Issues Affecting the Performance of Regional Fishery Bodies (FAO Doc. FI:RFB/99/2, Rome, FAO, 1999), n. 1). However, the title of the meeting, "Meeting of FAO and Non-FAO Regional Fishery Bodies and Arrangements", already suggests the difficulty of finding an appropriate chapeau. RFBs also include bodies like the International Council for the Exploration of the Sea (ICES) which collect scientific information and give advice to other RFBs.

7 Cf. R.R. Churchill, EEC Fisheries Law (Dordrecht, Boston, Lancaster, Martinus Nijhoff Publishers, 1987), p. 3. 
areas, it is often essential that fisheries management authorities co-operate in order to align their regulatory efforts. Non-alignment ${ }^{8}$ will eventually lead to declining catches in transboundary stocks on both sides of a maritime boundary. ${ }^{9}$ Which type of maritime zone ${ }^{10}$ the boundary separates is of no relevance.

While co-operation between fisheries management authorities, be it states or RFMMs, appears at first sight common sense and in the interest of the states involved, there are numerous reasons why such co-operation is not forthcoming. The complexity of fisheries management, even for single-species management, may make states or RFMMs hesitant about co-operation. On the other hand, growing awareness of the interdependence of targeted stocks and associated or dependent stocks and the advent of the ecosystem approach, should lead to wider recognition that co-operation has much to offer in dealing with complexities. Co-operation may nevertheless be hampered by the existence of disputes ${ }^{11}$ or differences (ideological, developmental or other) between the states concerned. Last, but not least, is the need to realise that "free-riders" may have more to gain in the absence of co-operation even though they knowingly act in a manner that is detrimental to the interests of other states and/or the international community.

\section{Treaty Law}

In recognising that co-operation is the only real solution to the management of transboundary stocks, international law has developed obligations to ensure that states engage in co-operation despite recognised difficulties. The two main global instruments that establish relevant frameworks for co-operation are the LOS

8 Note the central criterion of "compatibility" in the 1995 Fish Stocks Agreement (Art. 7). See A.G. Oude Elferink, The Impact of Article 7(2) of the Fish Stocks Agreement on the Formulation of Conservation and Management Measures for Straddling and Highly Migratory Fish Stocks (FAO Legal Papers Online No. 4, 1999) (www.fao.org/legal).

9 The term "transboundary stocks" intends to denote that the geographical area in which these stocks occur is not confined to the maritime zones of a single state, an RFMM's regulatory area or the high seas (see E. Hey, The Regime for the Exploitation of Transboundary Marine Fisheries Resources (Dordrecht, Martinus Nijhoff Publishers, 1989), p. 1). The terms "shared" or "joint" stocks are often used in the literature to refer to stocks that migrate between the maritime zones of two or more states (e.g. Churchill, note 7 above at p. 191). However, section 7.1.3 of the 1995 FAO Code of Conduct uses "transboundary stocks" to denote shared or joint stocks. R.R. Churchill, "Shared Fisheries Management in the European Community", (1993) 2 Review of European Community and International Environmental Law 260-268 at 260 argues that it is appropriate to speak of management of shared stocks in relation to the $\mathrm{EC}$, but of joint stockmanagement where it concerns the European Community (EC) and third states. "Straddling" stocks should preferably be used for stocks that migrate between EEZs and the high seas (cf. Art. 3(1) of the 1995 Fish Stocks Agreement). "Highly migratory species" and "highly migratory fish stocks" are distinct stocks that can migrate both between EEZs or EEZs and the high seas (cf. Art. 64 of the LOS Convention and Art. 3(1) of the 1995 Fish Stocks Agreement; see also notes 17 and 62 below).

10

E.g. on maritime delimitation or on the status of certain land territory. 
Convention and the 1995 Fish Stocks Agreement. The LOS Convention distinguishes between duties to co-operate in relation to the exploitation of particular species, ${ }^{12}$ and the exploitation of "non-specific"13 species in geographically defined areas, namely, species occurring in enclosed or semi-enclosed seas or on the high seas or straddling the boundaries of exclusive economic zones (EEZs) or of EEZs and the high seas. ${ }^{14}$ As the LOS Convention must be regarded as a framework convention in relation to the exploitation of marine living resources, it is noteworthy that it does not contain specific obligations to co-operate in relation to stocks occurring within the internal waters, territorial seas or archipelagic waters of two or more coastal states. ${ }^{15} \mathrm{~A}$ similar situation exists with respect to sedentary species on the continental shelf under national jurisdiction, although a need for co-operation would in such cases often be absent. ${ }^{16}$

12 Highly migratory species (Art. 64 and Annex I), marine mammals (Arts 65 and 120), anadromous stocks (Art. 66) and catadromous stocks (Art. 67).

13 I.e. those that are not covered by regimes for particular species (see note 12 above).

14 Arts 63, 116-120 and 122-123. An often cited difference between Arts 63(2) and 64 is that the former merely establishes a pactum de negotiando as it uses "seek to agree", whereas the latter uses "shall co-operate" and thus constitutes a pactum de contrahendo. However, A. Tahindro, "Conservation and Management of Transboundary Fish Stocks: Comments in the Light of the Adoption of the 1995 Agreement for the Conservation and Management of Straddling Fish Stocks and Highly Migratory Fish Stocks",(1997) 28 Ocean Development and International Law $1-58$ at 19 argues that this difference is not very significant.

15 In fact, the provisions in the LOS Convention which deal with these maritime zones do not, or hardly, stipulate how coastal states should manage fisheries. Obligations to co-operate nevertheless exist for enclosed or semi-enclosed seas pursuant to Art. 123(a) and with respect to anadromous stocks that "migrate into the waters landward of the outer limits of the [EEZ] of a State other than the State of origin" (Art. 66(4)). A similar exception does not seem to exist for catadromous stocks, where the phrase "through the [EEZ] of another State" (Art. 67(3)) is used. With respect to archipelagic waters, co-operation is in principle only explicitly necessary in relation to existing treaties with, and traditional fishing rights of, other States (Art. 51). See also the due regard obligation in Art. 58(2). Part XII of the LOS Convention on "Protection and Preservation of the Marine Environment" contains in Sections 1, 2 and 3 several general obligations which are applicable to the conservation of marine living resources (e.g. Arts 192, 193, 194(5) and 202). Particularly relevant here is that Art. 197 requires states to co-operate for the protection and preservation of the marine environment. Although the term "marine environment" is not defined in the LOS Convention, Art. 1(4) includes estuaries in the definition of "pollution of the marine environment". Thus, internal waters that are not physically separated from the territorial sea would at any rate be included. Relevant general obligations are also laid down in the Biodiversity Convention (Convention on Biological Diversity, Nairobi, 22 May 1992, in force 29 December 1993, (1992) 31 ILM 822, www.biodiv.org), for example in Art. 3. Particularly relevant here is that Art. 5 requires states to co-operate "for the conservation and sustainable use of biological diversity".

16 Art. 68 of the LOS Convention provides that "sedentary species as defined in" Art. 77(4) are not governed by Part V of the LOS Convention and thus are not subject to its range of obligations of co-operation (cf. Hey, note 9 above at p. 47). Accordingly, Art. 1(c) of the 1995 Fish Stocks Agreement excludes sedentary species as defined in Art. 77 of the LOS Convention. See also Art. 1 of the SEAFO (South East Atlantic Fisheries Organization) Draft Convention (Sixth Meeting, May 2000) which includes sedentary species under the scope of regulation except those subject to coastal state jurisdiction under Art. 77(4) of the LOS Convention. The text of the SEAFO Draft Convention as adopted at the Sixth Meeting is regarded as a more or less final draft and ready for signature. 
The range of obligations to co-operate under the 1995 Fish Stocks Agreement applies in principle to two stocks only: straddling fish stocks and highly migratory fish stocks. ${ }^{17}$ While the Agreement's geographical scope of application is not explicitly defined, Article 3 basically distinguishes between beyond or within "areas under national jurisdiction". As this phrase is not defined either, this causes uncertainty on the spatial application of the Agreement's obligations to cooperate. ${ }^{18}$ If interpreted literally, the phrase would indeed include not only the territorial sea but also archipelagic waters and even internal waters. However, the full title of the Agreement, particularly the term "implementation", already indicates that the Agreement should be seen as part and parcel of the LOS Convention. ${ }^{19}$ Only Part V of the LOS Convention, on the EEZ, contains provisions on straddling and highly migratory stocks (species) and these provisions simply provide no link to other maritime zones under national jurisdiction.

This confusing terminology in the Agreement was noted by Indonesia in the Fourth Session of the Multilateral High-Level Conference (MHLC) negotiation process on the establishment of a Western and Central Pacific Fisheries Organization (WCPFO), which will deal with the conservation and management of (certain) highly migratory fish stocks. ${ }^{20}$ Chairman Nandan, who also chaired the negotiations on the 1995 Fish Stocks Agreement, confirmed that it was his understanding that the Agreement's obligations extended in principle only to the EEZ but not further landward. Accordingly, Indonesia and the Philippines sought to ensure that their archipelagic waters would not form part of the WCPFO's Convention Area. ${ }^{21}$ If followed by the other archipelagic states in the

Obligations of co-operation are laid down virtually everywhere, for example in Arts 5 and 7, and Part III in its entirety. Arts 15 and 16 establish a marginally more specific regime for enclosed and semi-enclosed seas and areas of high seas surrounded entirely by an area under the national jurisdiction of a single state. Note that "highly migratory species", as referred to in Annex I to the LOS Convention, also include dolphins and cetaceans but that these species would not fall under the term "highly migratory fish stocks".

18 The phrase is used in Arts $3,7(1), 7(2), 7(2)(\mathrm{a}), 7(2)(\mathrm{d}), 7(7), 14(3)$ and 18(3)(b)(iv) and Art. 1(1) of Annex I.

19 See the first preambular paragraph and Art. 4. Also, para. 17.49(e) of Agenda 21 (Annex II to the Report of the United Nations Conference on Environment and Development, Rio de Janeiro, 3 to 14 June 1992, UN Doc. A/CONF.151/26) explicitly mentions the objective of implementation and the fact that "the results of the conference should be fully consistent with the provisions of" the LOS Convention.

20 The Sixth Session took place in Hawaii in April 2000. For an overview see T. Aqorau, "The Draft Convention for the Conservation and Management of Highly Migratory Fish Stocks in the Western and Central Pacific Ocean", (2000) 15 International Journal of Marine and Coastal Law 111-120. The Seventh Session (Hawaii, August/September 2000) was concluded with the adoption of the Convention on the Conservation and Management of Highly Migratory Fish Stocks in the Western and Central Pacific Ocean' on 5 September 2000, in Honolulu. The current article only takes account of the text as adopted at the Sixth Session.

Art. 3(1) of the WCPFO Draft Convention (Fourth Session), which, however, was drafted to include at least part of the territorial waters of the two states. Moreover, Indonesia and the Philippines agreed to para. (3) of Art. 3 under which they must co-operate in the collection and exchange of scientific data on highly migratory fish stocks in their archipelagic waters. 
area, ${ }^{22}$ this would have an enormous impact on the future operation of the WCPFO. The versions of the draft WCPFO Convention adopted at the Fifth and Sixth Sessions do not refer to archipelagic waters but do not provide a definition of a western and northern boundary for the proposed Convention Area either. The controversy therefore remains unresolved. ${ }^{23}$

\section{Customary International Law}

Treaty obligations on co-operation may be absent or not applicable to certain situations or between certain states. However, customary international law stipulates certain duties that must be taken into account in all these situations. Relevant here is the well-known postulate sic utere tuo ut alienum non laedas, ${ }^{24}$ which effectively imposes on states a duty to refrain from behaviour within their jurisdiction or control if this is detrimental to the rights of other states. 25 Consequently, where behaviour, including the exploitation of marine living resources, raises the risk of affecting the rights and interests of other states, the sic utere principle obliges the state engaging in this behaviour to exercise due diligence and seek co-operation with other states to avert these risks. ${ }^{26}$ The advent of the precautionary principle further strengthens this obligation by requiring states to do more and at an earlier stage. ${ }^{27}$

These include Fiji, Kiribati, the Marshall Islands, Papua New Guinea (PNG), the Philippines, the Solomon Islands, Tuvalu and Vanuatu. However, Kiribati, the Marshall Islands and Tuvalu may not yet have established archipelagic baselines in accordance with Art. 47 of the LOS Convention. Also, the Philippines claims internal waters instead of archipelagic waters. See E.J. Molenaar, Coastal State Jurisdiction over Vessel-Source Pollution (The Hague, Boston, London, Kluwer Law International, 1998), p. 348.

23 Note that Art. 7 (Fifth Session) on "Implementation of principles in areas under national jurisdiction", links in para. (1) the phrase "areas under national jurisdiction" with "sovereign rights", which would thus be limited to the EEZ. This is consistent with Art. 3(2) of the 1995 Fish Stocks Agreement (cf. F. Orrego Vicuña, The Changing International Law of High Seas Fisheries (Cambridge, Cambridge University Press, 1999), pp. 180-183). See the concern in the statements of Indonesia and PNG at the Fifth and Sixth Sessions, and by the Philippines at the Fifth Session, that archipelagic waters should not be included in the Convention Area. See also the position taken by Vanuatu at the Fifth Session. The exclusion of archipelagic waters appears at any rate accepted for the purpose of the assessment of contributions (see the Annex to the Chairman's Closing Statement at the Sixth Session). as not injure that of another."

This postulate has, inter alia, been recognised in international jurisprudence such as the Trail Smelter arbitration (United States of America v Canada, 1941, (1941) 35 American Journal of International Law 684 at 716) and more recently in the Nuclear Weapons Advisory Opinion (Legality of the Threat or Use of Nuclear Weapons (UNGA Request), 8 July 1996, [1996] ICJ Rep 66 at 242, para. 29) by the International Court of Justice (ICJ) and has been laid down in various international instruments (e.g. Art. 194(2) of the LOS Convention).

26 Hey, note 9 above at p. 41 regards the duty to co-operate as supplementary to the duty of due diligence.

27 Laid down, inter alia, in Arts 5(c) and 6 (Annex II) of the 1995 Fish Stocks Agreement. In the Southern Bluefin Tuna (Provisional Measures) cases (Southern Bluefin Tuna Cases (Nos. 3 and 4) (New Zealand v Japan; Australia v Japan), Requests for Provisional Measures, Order of 27 August 1999, www.un.org/Depts/los), the International Tribunal for the Law of the Sed (ITLOS) applied in fact the precautionary principle even though it did not explicitly say so (see 


\section{Implementing the Duty of Co-operation}

Fishing rights over transboundary stocks, whether based on sovereignty, sovereign rights or the freedoms of the high seas, are mostly, if not always, subject to the customary or conventional duties on co-operation. The precise implications of this duty are nevertheless highly dependent on the circumstances of each case. The status of the stocks in question and the significance of transboundary effects appear to be key factors in assessing these implications. ${ }^{28}$ The failure to reach agreement on co-operation does not absolve states or RFMMs from taking appropriate management measures, not excluding reduction in catch quotas or, in cases of extreme urgency, a moratorium on fishing. ${ }^{29}$ The issue of responsibility for the failure to reach agreement cannot be rigidly used as an excuse either, certainly not where the international community's interest in the conservation of marine living resources and biological diversity is at stake.

\section{Negotiation}

In its initial stages, co-operation will largely be a matter of negotiation. Account should therefore be taken of the following authoritative considerations by the International Court of Justice (ICJ) in the North Sea Continental Shelf cases, ${ }^{30}$ even though made in the context of maritime delimitation:

"the parties are under an obligation to enter into the negotiations with a view to arriving at an agreement, and not merely to go through a formal process of negotiation as a sort of prior condition for the automatic application of a certain method of delimitation in the absence of agreement; they are under an obligation so to conduct themselves that the negotiations

cont.

in particular paras 77 and 79-80). Judge Laing, in his Separate Opinion, submitted that "these statements are pregnant with meaning" (para. 13). See also the Separate Opinion by Judge Treves, who suggests that the precautionary approach is also relevant for deciding on the urgency of provisional measures (paras 8-9).

Also, transboundary effects are commonly larger in areas characterised by a larger extent of jurisdictional fragmentation.

29 In their Joint Declaration in the Southern Bluefin Tuna (Provisional Measures) cases before the ITLOS, Vice-President Wolfrum and Judges Caminos, Marotta Rangel, Yankov, Anderson and Eiriksson argue that, in light of the depleted and poor state of the stock, the ineffective cooperation among the states parties to the CCSBT Convention (Convention for the Conservation of Southern Bluefin Tuna, Canberra, 10 May 1993, in force 20 May 1994, www.home.aone.net.au/ccsbt), and the rising catches of non-parties, "a reduction in the catches of all those concerned in the fishery in the immediate short term would assist the stock to recover over the medium to the long term. Article 64 of the [LOS Convention] lays down, as stated in the Order, a duty to co-operate to that end". Note that the duty to co-operate does not involve the duty to agree on compatible measures (cf. Art. 7(4) of the 1995 Fish Stocks Agreement; Oude Elferink, note 8 above at p. 19).

30 North Sea Continental Shelf cases (Federal Republic of Germany v Denmark; Federal Republic of Germany v the Netherlands), Judgment of 20 February 1969, [1969] ICJ Rep 3. 
are meaningful, which will not be the case when either of them insists its own position without contemplating any modification of it." 31

These observations on the substantive standards that negotiations must meet, are in fact applications of the principle of good faith to specific circumstances. This principle has, inter alia, been laid down in Article 300 of the LOS Convention and was confirmed in the 1974 Fisheries Jurisdiction (Merits) cases ${ }^{32}$ where the ICJ indicated that the parties were "to conduct their negotiations on the basis that each must in good faith pay reasonable regard to the legal rights of the other". ${ }^{33}$

In the Southern Bluefin Tuna (Provisional Measures) cases, ${ }^{34}$ Japan argued that Australia and New Zealand had not exhausted procedures for amicable dispute settlement, such as negotiation, when they submitted the dispute to the International Tribunal on the Law of the Sea (ITLOS). Rather than assessing whether the negotiations met the criteria set by the ICJ in the North Sea Continental Shelf cases, the ITLOS simply held that the fact that Australia and New Zealand had stated that the negotiations had terminated was sufficient in the context of Part XV of the LOS Convention. ${ }^{35}$ It is indeed true that, under Part XV of the LOS Convention, none of the requirements that must be met before a dispute can be submitted to a compulsory procedure entailing binding decisions elaborates the substantive side of negotiations. Article 283(1) of the LOS Convention merely requires an exchange of views with the object of settling the dispute "by negotiation or other peaceful means". 36 The decision by the ITLOS is at any rate justifiable on account of the fact that Article 290(5) of the LOS Convention merely required the determination of prima facie jurisdiction. The Annex VII arbitral tribunal seized with the merits in this case confirmed that the requirement in Article 283(1) of the LOS Convention had been met as the "[n]egotations have been prolonged, intense and serious" and the parties to the dispute were not required to "negotiate indefinitely". ${ }^{37}$ This points to a more

32 Fisheries Jurisdiction case (United Kingdom v Iceland), Merits, Judgment of 25 July 1974, [1974] ICJ Rep 3; Fisheries Jurisdiction case (Federal Republic of Germany v Iceland), Merits, Judgment of 25 July 1974, [1994] ICJ Rep 175.

33

See note 27 above.

35 Order, paras 56-61. Professor Ando, Legal Counsel for Japan, explicitly referred to the observations made by the ICJ in the North Sea Continental Shelf cases cited in the main text (Verbatim Record, ITLOS/PV.99/23).

36

Southern Bluefin Tuna case (Australia and New Zealand v Japan), Arbitral Tribunal constituted under Annex VII of the LOS Convention, Award on Jurisdiction and Admissibility of 4 August 2000, www.worldbank.org/icsid, at pp. $96-97$, para. 55. See also the view expressed by the ICJ in the Land and Maritime Boundary Between Cameroon and Nigeria case (Cameroon v Nigeria), Preliminary Objections, Judgment of 11 June 1998, [1998] ICJ Rep 275, para. 56, which emphasises that, under general international law, the exhaustion of diplomatic negotiations is not a precondition for submitting a dispute to the ICJ. 
substantive assessment similar to the approach pursued by the ICJ in the North Sea Continental Shelf cases.

The 1995 Fish Stocks Agreement makes a (modest) contribution to further specifying the duty to co-operate by providing in Article 7(3) that " $[I] \mathrm{n}$ giving effect to their duty to co-operate, States shall make every effort to agree on compatible conservation and management measures within a reasonable period of time". Furthermore, Article 8(2) focuses on the need for states to engage in consultations in "good faith and without delay" where a threat of overexploitation exists or where a new fishery is being developed.

\section{Frameworks for Co-operation: The Preference for RFMMs}

Effective fisheries management can eventually only be achieved if initial efforts in negotiation lead to a more permanent and structured framework for cooperation. One of the preliminary issues that needs to be decided is at what level co-operation should take place, namely, bilateral, (sub)regional or global. Once again, the circumstances of each case are the decisive factor. The need for multispecies or ecosystem management ${ }^{38}$ and the geographical configuration will often call for regionalism. In fact, regulation at the regional level will more generally (not exclusively with regard to fisheries) offer advantages over bilateral or global approaches. ${ }^{39}$

As the LOS Convention is largely a framework convention, it does not rigidly dictate at which level co-operation should take place. ${ }^{40}$ Although the 1995 Fish Stocks Agreement shares many of the characteristics of the LOS Convention, it is more explicit in its support for regional regulation through RFMMs. ${ }^{41}$ Partially, this is due to the fact that its scope is limited to straddling and highly migratory fish stocks. Part III on "Mechanisms for International Co-operation Concerning Straddling Fish Stocks and Highly Migratory Fish Stocks" starts out with the pivotal Article 8 on "Co-operation for Conservation and Management". Whereas the first paragraph basically reaffirms the discretion

The FAO's Committee on Fisheries (COFI) has advocated the use of subregional bodies, which could be more efficient than ocean-wide regional organisations (J. Swan and B.P. Satia, Contribution of the Committee on Fisheries to Global Fisheries Governance 1977-1997 (FAO Doc. FIPL/C938, Rome, FAO, 1998), p. 34).

40 Whereas a preference for (sub)regional approaches exists in Arts 64(1), 66(5) and 118, Art. 63 seems to envisage anything but global approaches. Conversely, Arts 66(4) and 67(3) only mention bilateral co-operation. The term "appropriate" in Arts 63(1) and (2), 64 and 65 further reaffirms the wide margin of discretion in deciding on the level of co-operation. In Art. 118, this same term reflects the recognition that establishing an organisation may not even be necessary or the most effective solution.

41 Cf. M. Hayashi, "The 1995 Agreement on Straddling Fish Stocks and Highly Migratory Fish Stocks: Significance for the Law of the Sea Convention", (1995) 29 Ocean and Coastal Management 51-69 at 58. The 1995 Fish Stocks Agreement can be regarded as a set of globally agreed principles under which RFMMs should be established and operate (cf. Orrego Vicuña, note 23 above at p. 202). 
in opting for a level of co-operation, the succeeding paragraphs all reflect the preference for RFMMs. This is particularly evident in the obligation to participate in existing RFMMs, the exclusion of non-participants from fishing in the regulatory areas of existing RFMMs, and the obligation to establish RFMMs in (sub)regions where these are absent. ${ }^{42}$ Furthermore, Articles 9-13 are all devoted to RFMMs. The ensuing discussion will devote ample attention to these obligations.

\section{Spatial Scope of the RFMM's Regulatory Area}

An RFMM's success in management depends to an important degree on the spatial scope of its regulatory area. ${ }^{43}$ At first sight it seems sensible that the pursued management approach would be the predominant factor in determining the spatial scope. Due to the advent of more sophisticated management approaches, namely, from single-species approaches to multi-species and ecosystem management, regulatory areas would be expected to expand correspondingly. Instead of having to concentrate only on the spatial distribution of the target stock, it has also become necessary to take into account the spatial distribution of associated or dependent species or even other factors and activities with an impact on management, such as pollution. ${ }^{44}$

Tailored to the ecosystem approach would be a division of seas and oceans in Large Marine Ecosystems (LMEs), which have been described as "regional phenomena [which possess] distinguishing characteristics that differentiate them from other areas of the earth's surface, and separated from neighboring areas by physical boundaries". 45 These characteristics are unique hydrographic regimes,

42 Paras (3), (4) and (5) respectively. Note that Art. 8(5) thus goes further than Art. $63(2)$ of the LOS Convention.

43 An RFMM's regulatory area is not necessarily identical to its "Convention Area". See Art. I(1) and (2) of the NAFO Convention (Convention on Future Multilateral Co-operation in the Northwest Atlantic Fisheries, Ottawa, 24 October 1978, in force 1 January 1979, www.nafo.ca). This publication generally uses "regulatory area" to denote the spatial area in which the main competences of the RFMM apply. More often than not, this will not include coastal states' maritime zones. For example, in the SEAFO process, Japan continues its reservation at the exclusion of relevant EEZs in the Convention Area (Explanatory Note Sixth Meeting and Art. 4 of the SEAFO Draft Convention (Sixth Meeting)).

44 An ecosystem approach has, inter alia, been incorporated in Art. 5(d) of the 1995 Fish Stocks Agreement and in Art. II(3)(c) of the CCAMLR Convention (Convention on the Conservation of Antarctic Marine Living Resources, Canberra, 20 May 1980, in force 7 April 1982, (1980) 19 ILM 837, www.ccamlr.org). A very recent approach is the incorporation of "abundance-based management" in the 1999 Pacific Salmon Agreement (1999 Agrecment between Canada and the United States under the Pacific Salmon Treaty, Washington DC, 30 June 1999, in force 30 June 1999, www.dfo-mpo.gc.ca/pst-tsp; see e.g. Section 2, Chapter 1, Anncx IV), which is designed to ensure conservation in the face of as yet not fully understood fluctuations in salmon populations.

45 L.M. Alexander, "Large Marine Ecosystems as Global Management Units" in K. Sherman and L.M. Alexander (eds), Biomass Yields and Geography of Large Marine Ecosystems (Boulder, CO, Westfield Press, 1989), pp. 339-344 at p. 339. 
submarine topography and trophically dependent populations. ${ }^{46}$ But while this division would be quite ideal from a scientific perspective, even those that advocate the ecosystem approach linked to LMEs, acknowledge the limited potential of it being actually applied in practice. Even with consensus on the distinguishing characteristics, the existing jurisdictional fragmentation and other non-legal factors, including the sheer complexity of ecosystem management, will often be insurmountable stumbling blocks. ${ }^{47}$ Nevertheless, in cases where these other factors do not weigh so heavily, LMEs would be the appropriate point of departure. So far, the area of application of the CCAMLR Convention is the only LME linked to ecosystem management. ${ }^{48}$ Other potentially successful situations would appear to be enclosed and semi-enclosed seas. ${ }^{49}$

The current body of international law relating to (sub)regional co-operation in the management of transboundary stocks also recognises that the regulatory area of RFMMs is not exclusively, or even predominantly, determined by the spatial coverage of marine ecosystems or LMEs. While it might be argued that the LOS Convention implicitly supports an ecosystem approach due to the fact that it purports to be a "Constitution for the Oceans" and recognises that "the problems of ocean space are closely interrelated and need to be considered as a whole", ${ }^{50}$ the geographical dimension of marine ecosystems is nowhere explicitly held relevant for the spatial scope of regional co-operation. Rather, reference is made only to the existence of transboundary stocks, either exclusively target stocks or also associated species. ${ }^{51}$ More specifically, it is not even stipulated that

Ibid.

47 Cf. ibid. at pp. 339-341; J. Morgan, "Large Marine Ecosystems in the Pacific Ocean" in Sherman and Alexander, note 45 above at pp. $377-394$ at pp. 378 and 381. Note 44 above. See Art. 1 of the CCAMLR Convention.

49 Cf. Morgan, note 47 above at p. 381, who also mentions the case of an LME being within the maritime zones of a single state. This situation will not be further elaborated as it does not raise the issue of inter-state co-operation. See also the suggestions by Alexander, note 45 above at $\mathrm{p}$. 342; and by J.R.V. Prescott, "The Political Division of Large Marine Ecosystems in the Atlantic Ocean and Some Associated Seas" in Sherman and Alexander, note 45 above at pp. 395-442 at pp. 435-437. It can be argued that there are already several cases where RFMMs exist in enclosed or semi-enclosed seas, even though these RFMMs do not necessarily pursue an ecosystem management approach, for example the International Baltic Sea Fishery Commission (IBSFC).

50 Remarks by T.T.B. Koh, President of the Third United Nations Conference on the Law of the Sea (UNCLOS III), made at the final session at Montego Bay; Preamble to the LOS Convention. M.H. Belsky, "Developing an Ecosystem Management Regime for Large Marine Ecosystems" in Sherman and Alexander, note 45 above at pp. 443-468 more or less takes this approach.

51 Transboundary target stocks is the single criterion in Arts 64, 66 and 67 (Art. 64 also refers simply to "the region"). While Art. 63(1) and (2) uses "same stock or stocks of associated species", references to "fishing patterns [and] the interdependence of stocks" appear in Arts 61(3) and 119(1)(a) and to "effects on species associated and dependent upon harvested species" in Arts 61(4) and 119(1)(b). 
the entire spatial distribution of these stocks should be covered, although that would of course be crucial to meaningful management. ${ }^{52}$

The matter is addressed somewhat more straightforwardly in the 1995 Fish Stocks Agreement, where Article 9(1)(b) provides that, in establishing RFMMs for straddling and highly migratory fish stocks, states shall agree on:

"the area of application, taking into account article 7 , paragraph 1 , and the characteristics of the subregion or region, including socioeconomic, geographical and environmental factors."

The reference to Article 7(1) appropriately precedes the other factors. This provision contains the main coastal and flag states' rights and obligations over straddling and highly migratory fish stocks. Although neither the LOS Convention nor the 1995 Fish Stocks Agreement prescribes that an RFMM's regulatory area should include EEZs, states will more likely agree to include EEZs if it concerns highly migratory fish stocks. ${ }^{53}$ Which competence an RFMM would have within its regulatory area, or specifically those parts that consist of coastal states' maritime zones, is of course a separate issue.

Whereas the reference to Article 7(1) essentially concerns the type of maritime zones, the central criterion of Article $9(1)(b)$ is the "characteristics of the subregion or region". Three examples are mentioned, namely, "socioeconomic, geographical and environmental factors", but due to its non-exhaustive nature other "characteristics" could be relevant as well. ${ }^{54}$ In this context, subparagraphs (a) and (c) of Article 9(1) are of particular relevance:

"(a) the stocks to which the conservation and management measures apply, taking into account the biological characteristics of the stocks concerned and the nature of the fisheries involved;

(c) the relationship between the work of the new organization or

Section 7.3.1 of the 1995 FAO Code of Conduct emphasises that effective fisheries management requires the determination of the "entire area of distribution". Section 7.3 .2 subsequently provides that the management of transboundary stocks "throughout their range" requires compatibility (see also section 6.12). However, sections 7.1.3 7.1.4 merely refer to the existence of transboundary stocks, just like the relevant provisions of the LOS Convention.

In the MHLC process, the inclusion of archipelagic waters in the future Convention Area is controversial, but not of EEZs. See also the broad definition of the Area of Competence in Art. II of the IOTC Agreement (Agreement for the Establishment of the Indian Ocean Tuna Commission, Rome, 25 November 1993 (105th Session of the FAO Council), in force 27 March 1996, www.seychelles.net/iotc).

54 Upon signature of the 1995 Fish Stocks Agreement, the EC made the following interpretative declaration: "The European Community and its Member States understand that the terms 'geographical particularities", 'specific characteristics of the sub-region', "socio-economic, geographical and environmental factors', 'natural characteristics of that sea' or any similar terms employed in reference to a geographical region do not prejudice the rights and duties of States under Intcrnational Law." 
arrangement and the role, objectives and operations of any relevant existing fisheries management organizations or arrangements."

Although therefore not explicitly incorporated in subparagraph (b), stock characteristics and the regulatory area of an existing RFMM should certainly be taken into account. ${ }^{55}$ Moreover, the spatial coverage of marine ecosystems or LMEs could also be regarded as a relevant "characteristic", whether or not by treating it as an "environmental" factor. At the same time, marine ecosystems or LMEs are certainly not taken as the central criterion but could be merely one of the factors relevant for the spatial scope of the regulatory area. ${ }^{56}$

Indicative of the wide range of relevant factors is the Information Note on Matters Before the Fourth Session in the MHLC. Paragraphs 5-8 of the Note clearly reflect that the spatial coverage of the prospective RFMM is dependent on a variety of considerations, the most important of which are:

- the need to ensure wide enough coverage of a highly migratory fish stock to pursue conservation and management objectives effectively;

- the need to ensure wide enough coverage for data collection and scientific monitoring;

- the need to avoid partial coverage of areas under national jurisdiction;

- the need to reconcile overlapping competences between organisations;

- the need to avoid gaps between jurisdictions of fisheries management organisations to avoid areas where no conservation and management measures would apply; and

- the need for clarity for both parties and non-parties as to the area of application of enforcement measures in order to avoid disputes. ${ }^{57}$

55 The chapeau of Art. 7(2) observes that compatibility is necessary to manage transboundary stocks "in their entirety" (which is similar to sections 6.12 and 7.3.2 of the 1995 FAO Code of Conduct). Tahindro, note 14 above at p. 15, suggests that "in their entirety" refers to the stocks concerned "throughout their geographical range". Also, subpara. (d) of Art. 7(2) refers to "the biological unity" to ensure that, in determining management measures, account is taken of their impact on the stock's entire geographical range and not merely their impact in the area of application (cf. Oude Elferink, note 8 above at p. 10). The CCSBT Convention does not have a regulatory area but is rather concerned with the conservation and management of one particular species, Southern Bluefin tuna, wherever the species occurs (see Art. 1). As the species also occurs within the regulatory area of the IOTC Agreement (Art. II), Japan has sought to establish an SBT Working Party or Sub-Commission. At its Third Session (1998), the IOTC adopted the "Resolution on Southern Bluefin Tuna" which, inter alia, reaffirms the prime responsibility of the CCSBT over southern bluefin tuna and agrees to review the matter at its Fourth Session (1999, report available at www.seychelles.net/iotc). However, the author was informed that the establishment of a Temperate Tuna Working Group could only barely be averted during the Fourth Session.

56 It is notable that, in relation to new members or participants. Art. 11 of the 1995 Fish Stocks Agreement does not even refer to the migratory range of stocks, let alone the spatial scope of marine ecosystems. One explanation is that it was drafted mainly with flag states in mind as coastal states would already be involved in the establishment phase pursuant to Art. 9 . 
Taking account of all these factors and attributing appropriate weight to each of them is obviously an extremely difficult task. ${ }^{58}$ It is easy to understand that in light of the unique characteristics of each region, the 1995 Fish Stocks Agreement, and the LOS Convention for that matter, could not contain more than a framework which needs to be implemented at the regional level.

\section{Participation in RFMMs: Rights and Duties}

Part and parcel of the issue of the spatial scope of an RFMM's regulatory area is the issue of participation: which states or other actors have rights or duties to participate in RFMMs ${ }^{99}$ It may be evident that these rights and duties vary first of all with the type of stocks and their geographical range. For example, where a transboundary stock occurs within the maritime zones of coastal states exclusively (shared or joint stocks), only these states will in principle have a right and/or a duty to participate in an RFMM which manages that stock. ${ }^{60}$ Where, on the other hand, the transboundary stock occurs partially or entirely on the high seas, the matter becomes far more complex due to the (qualified) freedom of fishing on the high seas, which all states are entitled to exercise. ${ }^{61}$

Although it has been argued that a duty to co-operate exists with respect to most, if not all, transboundary stocks, the discussion above revealed that cooperation may take many forms and does not automatically translate into a duty to participate in an already existing RFMM or to cstablish one. This absence of an explicit duty to participate has led to Article 8(3) of the 1995 Fish Stocks Agreement, which provides:

"Where a subregional or regional fisheries management organization or arrangement has the competence to establish conservation and management measures for particular straddling fish stocks or highly migratory fish stocks, States fishing for the stocks on the high seas and relevant coastal States shall give effect to their duty to cooperate by becoming members of

57 Information Note on Matters Before the Fourth Session of the Multilateral High-Level Conference on the Conservation and Management of Highly Migratory Fish Stocks in the Western and Central Pacific, part of the documents distributed for the Fourth Session, para. 8 . A similar recognition is apparent in the Report of the Meeting of FAO and Non-FAO Regional Fishery Bodies or Arrangements (FAO Doc. FIPL/R597, Rome, FAO, 1999), para. 31.

58 A similar task must be undertaken in order to achieve "compatibility" and to determine the nature and extent of participatory rights of new participants under Arts 7(2) and 11 of the 1995 Fish Stocks Agreement respectively (on Art. 7(2) see Oude Elferink, note 8 above).

59 Consistent with the definition of an RFMM (see the text accompanying note 6 above) and the structure of Art. 8(3) of the 1995 Fish Stocks Agreement (see below in the main text), participation includes being a member of an organisation or participation in an arrangement, but not voluntarily applying management measures.

60 This right is based on their sovereignty or sovereign rights over the exploitation of marine living resources in their maritime zones (Arts 19(2)(i), 22(1)(d), 56(1)(a) and 77(1) of the LOS Convention). A special case could be states with traditional fishing rights under Art. 51(1) of the LOS Convention.

61 Arts $87(1)(\mathrm{e})$ and 116 of the LOS Convention. 
such organization or participants in such arrangement, or by agreeing to apply the conservation and management measures established by such organization or arrangement. ..."

As this provision indicates, this duty to participate is in fact a specification of the duty to co-operate. States can also apply the RFMM's conservation and management measures as an alternative to participation. The provision's operative scope is confined to two types of transboundary fish stocks, namely, those that are straddling or highly migratory. However, this will probably cover most fish stocks that occur on the high seas. ${ }^{62}$

A preliminary condition which must be fulfilled before the core duties of Article 8(3) arise, is that the existing RFMM "has the competence to establish conservation and management measures" etc. Article 1(1)(b) of the 1995 Fish Stocks Agreement defines "conservation and management measures" as "measures to conserve and manage one or more species of living marine resources that are adopted and applied consistent with the relevant rules of international law as reflected in the [LOS Convention] and this Agreement". ${ }^{63}$ These substantive requirements must therefore all be met before the duties in Article 8(3) are triggered. The words "competence to establish" in Article 8(3) seem to imply merely that the instrument establishing the RFMM must confer such a competence on one of its bodies. It is certainly not evident that the competence of the RFMM itself is at issue, for example due to the fact that it bars certain states from participating. ${ }^{64}$ As no reference is made to the legal status of the measures, e.g. recommendatory or legally binding, the presumption is that non-participants must comply in the same manner and to the same extent as participants, provided, of course, they are Parties to the 1995 Agreement.

Paragraph (3) of Article 8 of the 1995 Fish Stocks Agreement should be read

Cf. Orrego Vicuña, note 23 above at p. 55. Determining whether species are highly migratory in the sense of Art. 64 of the LOS Convention is simple: it concerns exclusively the stocks listed in Annex I to the LOS Convention. The obligations in Art. 64 only apply to these species (see also notes 9 and 17 above). The term "straddling" is not defined in either the LOS Convention or the 1995 Fish Stocks Agreement, and should therefore be regarded as those stocks to which Art. 63(2) of the LOS Convention refers.

Note the similarity with the definition of "international conservation and management measures" in Art. I(b) of the 1993 FAO Compliance Agreement (Agreement to Promote Compliance with International Conservation and Management Measures by Fishing Vessels on the High Seas, Rome, 24 November 1993, not in force, (1994) 33 ILM 969; as at 1 September 2000, 14 acceptances were received (25 needed)).

The key question is of course whether management measures by RFMMs are opposable to nonparticipants. D.A. Balton, "Strengthening the Law of the Sea: The New Agreement on Straddling Fish Stocks and Highly Migratory Fish Stocks", (1996) 27 Ocean Development and International Law 125151 at 139 , submits that it could well be argued that excluding nonparticipants to an RFMM from fishing on the high seas amounts to a violation of Art. I(1)(b) of the 1995 Fish Stocks Agreement. Alternatively, the present author's approach focuses on the concept of "real interest" in relation to the rights and duties on participation in RFMMs (see below). See also NAFO's future expectations strategy discussed at pp. $000-000$ below. 
together with paragraph (4), which essentially provides that only those states that comply with any of the alternatives in paragraph (3) "shall have access to the fishery resources to which those measures apply". The right of access is thereby linked directly to the duty either to participate in the RFMM or to apply its management measures. This linkage between right and duty implies that states that do not comply with any of these options are effectively excluded from exercising the freedom of fishing on the high seas. ${ }^{65}$ Together with a call for appropriate measures against vessels flying the flag of non-participants in RFMMs, ${ }^{66}$ this approach is helpful in countering the use of flags of convenience to evade international management measures. These much stronger and explicit duties on co-operation are only applicable between states parties to the 1995 Fish Stocks Agreement and therefore not inconsistent with the pacta tertiis principle. ${ }^{67}$

Voluntary application of conservation and management measures is included as an alternative to participation in an RFMM, but it is doubtful whether it will be used apart from special situations. Although conservation and management measures could cover the entire range of tools used for fisheries management, the single most important one is obviously that which generally constitutes the very basis of prevention of over-fishing: the total allowable catch (TAC) and its allocation. ${ }^{68}$ The negative impact of non-compliance with this type of measure will probably always outweigh the positive impact of compliance with measures such as minimising discards, by-catch and even those establishing minimum fish

Cf. Hayashi, note 41 above at p. 58. Contra Orrego Vicuna, note 23 above at p. 209, who treats the matter more as a further step in the regulation of high seas fishing. See also Art. 17(2) of the 1995 Fish Stocks Agreement. Although para. (3) of Art. 8 refers to both flag and coastal states and para. (4) to states in general, para. (4) is in principle not directed at coastal states. Imposing restrictions of this magnitude on the coastal state's sovereign rights would not only be a considerable departure from the LOS Convention but also inconsistent with the scope of application of the 1995 Fish Stocks Agreement (Art. 3(1)). See Arts $17,21,22$ and 33, the last of which is aimed at vessels flying the flag of non-parties to the 1995 Fish Stocks Agreement.

67 This is despite the fact that Art. 8 uses "States" and not "States Parties". See Arts 1(2)(a) and 33 of the 1995 Fish Stocks Agreement. However, Orrego Vicuña, note 23 above at p. 209 regards the 1995 Fish Stocks Agreement as "an objective regime under international law, governing not only relations between parties to it but also the conduct of activities of other states in a particular area". Furthermore, on p. 214 he submits that a state non-party to the 1995 Fish Stocks Agreement may even feel the impact of its provisions through its being a party to the LOS Convention. This view proceeds from the argument that the 1995 Fish Stocks Agreement implements certain LOS Convention provisions.

The use of "allocation" is intended to comprise all management measures intended to allocate a share in the TAC, such as quotas and limited fishing effort (including closed areas/seasons) or the type of allocation applied for instance by CCAMLR (i.e. closing the fishing season once catch reports indicate that the TAC is reached). See also the examples in Art. 10(b) of the 1995 Fish Stocks Agreement, which provides that, within an RFMM, states shall "agree, as appropriate, on participatory rights such as allocations of allowable catch or levels of fishing effort". Management through limited fishing effort is generally also based on catch estimations and thus has an effect similar to the TAC. For some special types of fisheries, however, a TAC is not necessary but merely the protection of spawning grounds. 
or mesh sizes. Ultimately, non-compliance with TAC allocations must lead to the RFMM's management failure. Illustrative of this are provisions in instruments on regional fisheries management which basically regard engaging in fishing activities by non-participants as undermining the effectiveness of the management objectives, and thereby not merely justify but effectively require appropriate measures by the participants. ${ }^{69}$ These provisions do not refer to non-compliance with such subsidiary measures as regulations on by-catch or discards.

In general, an RFMM will not be prepared formally to reserve a TAC allocation for non-participants. ${ }^{70}$ Consequently, voluntary participation is generally not a viable alternative, even though it may be useful in special situations,${ }^{71}$ for instance, where the RFMM's institutional instrument does not

These measures include "notes verbales" and other forms of diplomatic pressure (see R. Barston, "The Law of the Sea and Regional Fisheries Organisations", (1999) 14 International Journal of Marine and Coastal Law 333-352 at 352), trade measures or prohibitions of entry into port, landing of catch or transhipment at sea. Justification for these measures is generally sought in the non-participants' disregard for the obligation to co-operate under Art. 118 of the LOS Convention, or as the NAFO Compliance Scheme ("Scheme to Promote Compliance by NonContracting Party Vessels with the Conservation and Enforcement Measures Established by NAFO", NAFO/GC Doc. 97/6, www.nafo.ca) puts it, "the duty to have due regard to established fisheries". See also CCAMLR Conservation Measure 118/XVII entitled "Scheme to Promote Compliance by Non-Contracting Party Vessels with CCAMLR Conservation Measures" (text available al www.ccamlr.org). Norway, for instance, may deny an application for a licence to fish in its maritime zones if the vessel or the vessel's owner has taken part in unregulated fishing on the high seas of a fish stock which is subject to regulation in Norway's maritime zones or if the fishing operation would contravene regulatory measures laid down by RFMMs (CCAMLR-XVIII, para. 5.18 and the relevant Norwegian Working Paper, SCOI 99 19). These measures are not considered a violation of the obligation not to discriminate under Art. 119(3) of the LOS Convention as they do not target specific states but rather all states that are deemed to be non-co-operative (see also Orrego Vicuña, note 23 above at pp. 47-48 and 70 71). Tahindro, note 14 above at p. 27 , concludes therefore that the duty of co-operation in Art. 118 effectively means a duty to participate in an RFMM (cf. Division for Ocean Affairs and the Law of the Sea, Office of Legal Affairs, The Law of the Sea-The Regime for High Seas Fisheries. Status and Prospects (Sales No. E.92.V.12, New York, UN, 1992), para. 90, p. 28). The obligation laid down in Art. 8(3) of the 1995 Fish Stocks Agreement would in that view merely seem to have a confirmatory nature. As a final observation, it should be noted that the above line of reasoning does not hold if the non-participant wants in fact to participate in the RFMM but this is denied despite the presence of a "real interest". The legitimacy of the measures with which it is faced would in that case be debatable.

30 An RFMM's institutional instrument will often not allow for settig aside a share for nonparticipants (see the comments by the United States in Annex 6 to NAFO GC Doc. 99/4, under "Real Interest"). Exceptions nevertheless exist, e.g. under ICCAT (International Commission for the Conservation of Atlantic Tunas), for instance Resolutions 97-17 and 98-5 (available at www.iccat.es), and under Art. 20(2)(c) of the SEAFO Draft Convention (Sixth Meeting). Also, such an allocation would in itself not be opposable to non-participants (without their consent); it could be regarded as insufficient or it could in fact be an incentive to continue non-participation. However, catch estimates of non-participants should of course always be a relevant factor in setting the TAC. For example, the TAC on which the CCSBT last agreed is 11,750 tonnes but the stock assessment is based on a much higher catch estimate (higher even than the extra 2,250 tonnes which non-members of the CCSBT Convention are urged not to exceed pursuant to the "Action Plan Concerning the Promotion of Accession to, and Co-operation with, CCSBT by 
allow accession of a stakeholder and/or a TAC allocation has been agreed upon informally. In most situations, however, an RFMM does not reserve a TAC allocation for non-participants, and a flag state pursuing the alternative of voluntary application would thereby effectively bar itself from exercising its right to fish. As this is not likely to happen and participation in an RFMM in such cases the only real option, the right to participate and the terms on which this right is made conditional are of paramount importance. On this issue, the remainder of Article 8(3) of the 1995 Fish Stocks Agreement stipulates:

"States having a real interest in the fisheries concerned may become members of such organization or participants in such arrangement. The terms of participation in such organization or arrangement shall not preclude such States from membership or participation; nor shall they be applied in a manner which discriminates against any State or group of States having a real interest in the fisheries concerned." 72

Existing RFMMs are thus held to accept states with a "real interest in the fisheries concerned" as eligible to participate. Their terms of participation should be drawn up accordingly and applied in a non-discriminatory manner. ${ }^{73}$ The linchpin is of course the meaning of "real interest in the fisheries concerned". As participation in an RFMM is commonly linked to a share in the TAC, existing participants could be tempted to interpret and apply Article 8(3) restrictively so as not to see their shares in the TAC decrease. On the other hand, they may also realise that an interpretation or application which is inconsistent with Article $8(3)$, would give a rebuffed state a legal ground to ignore at least partially an RFMM's management measures. The RFMM's management measures would in such a situation not be opposable to it and have clear implications for the RFMM's effectiveness.

The 1995 Fish Stocks Agreement does not define the concept of "real interest". Nevertheless, a need was apparently felt not to repeat the key element of Article 118 of the LOS Convention, which refers to "States whose nationals

cont.

Non-Member States and Entities", adopted at CCSBT4(2), as Attachment F to the Report). An allocation for all non-participants collectively, or even specified individually, could also be linked to assessing whether fishing activities by non-participants are undermining the effectiveness of the RFMM. This avenue could be open to the CCSBT (note that, for instance, Taiwan has unilaterally agreed to limit its catch of southern bluefin tuna to 1,450 tonnes and is also questioned for alleged quota excesses; Report of CCSBT4(1), Agenda Item 7). Note also the way in which CCAMLR allocates TAC (note 68 above). Cf. Barston, note 69 above at p. 350 .

72 Emphasis added.

73 The issue of terms for participation is addressed below. 
exploit ... living resources" on the high seas ${ }^{74}$ Attention should also be drawn to Article 11 which gives some guidance for the determination of "the nature and extent of participatory rights" for new participants in RFMMs by providing that the following factors shall be taken into account:

(1) the status of the straddling fish stocks and highly migratory fish stocks and the existing level of fishing effort in the fishery;

(2) the respective interests, fishing patterns and fishing practices of new and existing members or participants;

(3) the respective contributions of new and existing members or participants to conservation and management of the stocks, to the collection and provision of accurate data and to the conduct of scientific research on the stocks;

(4) the needs of coastal fishing communities which are dependent mainly on fishing for the stocks;

(5) the needs of coastal States whose economies are overwhelmingly dependent on the exploitation of living marine resources; and

(6) the interests of developing States from the subregion or region in whose areas of national jurisdiction the stocks also occur.

Careful reading reveals that these factors are primarily relevant in relation to participatory (fishing) rights once it has been established that a "real interest" exists. ${ }^{75}$ At the same time, it should not be ruled out altogether that these factors are regarded as having a certain subsidiary relevance in the first stage, namely, verifying the presence of a "real interest". ${ }^{76}$

States or other actors with a "real interest"

Without clear guidance as to the meaning of the phrase "real interest in the fisheries concerned", its object and purpose will be examined in the context of the 1995 Fish Stocks Agreement. From the structure of Article 8(3) it is evident

74 Barston, note 69 above at p. 350 observes that a Chilean amendment of 24 July 1995 to include the word "real" before "interest" in UN Doc. A/CONF.162/22, of 11 April 1995, was accepted but not a cross-reference to Art. 118 of the LOS Convention (see also para. 17.60 of Chapter 17 of Agenda 21). He also submits that the Chilean proposal was aimed at interpreting Art. 118 of the LOS Convention narrowly in order to "prevent the proliferation of regional organisations and limit distant water fishing states' entry". Note that the obligation not to discriminate as laid down in Art. 8(3) of the 1995 Fish Stocks Agreement serves more or less the same purpose as Art. $119(3)$ of the LOS Convention.

75 Cf. the views of Canada, Denmark, France and Norway in the 1999 Report of the NAFO Allocation Working Group (GC Doc. 99/4, section 4). The discussion in the ICCAT Allocation Working Group revealed that many delegations also regarded Art. 11 as useful for the reconsideration of allocation criteria for existing participants.

76 J. Swan, "Implementation of the Law of the Sea Convention. Straddling and Highly Migratory Fish Stocks and High Seas Fishing" (paper presented at the 31st Annual Conference of the Law of the Sea Institute, Miami, March 1998), p. 7, suggests that Art. 11 is a reference for consideration in relation to the concept of real interest. See also the arguments used by Canada and the $\mathrm{EC}$ in their requests to become full participants in the MHLC process and those by Japan in Annex 7 to NAFO GC Doc. 99/4. 
that "States fishing for the stocks on the high seas and relevant coastal States", are at any rate included among states with a "real interest". ${ }^{77}$ Their "real interest" is implicit in their duty to participate. Relevant coastal states would be those states whose maritime zones are included in, or adjacent to, the RFMM's regulatory area. ${ }^{78}$ In addition, "States fishing" would be flag states that are actually engaged in fishing for the stock concerned at the time of their application to participate. ${ }^{79}$ For these states the very activity of fishing thus triggers both a duty and a right to participate. Added to these preliminary findings is the assumption that the phrase "real interest in the fisheries concerned" must have a wider purpose than merely referring to the two categories of states above. Otherwise it would have been sufficient to use "such States", as is done further on in Article 8(3), or a reference similar to that.

At first sight, this supplementary purpose does not readily explain the absence of the concept of "real interest" in paragraph (5) of Article 8, where the obligation to co-operate in the establishment of new RFMMs is only directed towards "relevant coastal States and States fishing on the high seas". This could be a simple oversight in drafting. ${ }^{80}$ Alternatively, it could have been omitted in order to spare the negotiation process unnecessary complications by arguing that states not admitted to the negotiation process could always invoke their right to participate under Article 8(3) after the RFMM is established. ${ }^{81}$

As a matter of logic, the group of states covered by the words "real interest" must be broader than the two categories of states mentioned above. At the same time, its presumed supplementary purpose means that the number of states eligible to participate is intended to decrease.$^{82}$ Otherwise it would have been sufficient to repeat the relevant terms of Article 118 of the LOS Convention and leave out the concept of "real interest" altogether. Consequently, it seems that under the terms of the 1995 Fish Stocks Agreement fewer states have a right to participate in an RFMM than under the LOS Convention, even though the latter instrument does not address the issue through rights of participation. Voluntary adherence to the 1995 Fish Stocks Agreement ensures that this "renunciation of rights", as one could arguably perceive it, does not conflict with the pacta tertiis principle.

It is submitted that three categories of states would be relevant to this supplementary purpose of the concept of "real interest":

77

Cf. the view of the United States in Annex 6 to NAFO GC Doc. $99 / 4$

Cf. Arts 1(c) and 26(1) of the SEAFO Draft Convention (Sixth Meeting)

The issue of non-state actors is dealt with below.

However, Art. 9(2) provides that states co-operating in the establishment of an RFMM "shall inform other States which they are aware have a real interest in the work of the proposed [RFMM] of such co-operation". Although not explicitly stated, one would expect that this would be followed by an invitation to participate in the negotiation process. See also the view of the United States in note 83 below.

See the resolution adopted during the Fifth Session, on 15 September 1999, in the MHLC process below.

See the views held by Barston, note 69 above. 
(1) flag states that fished in the regulatory area previously and want to resume fishing;

(2) flag states without a catch history that want to fish in the future; and

(3) states with no intention to fish that nevertheless want to participate in an RFMM.

The main reason why a state would want to apply under category (3) is to further the international community's interest in sustainable management and safeguarding biodiversity. ${ }^{83}$ The qualification to the criterion of "real interest", namely, "in the fisheries concerned", would not appear to pose problems. In addition, the phrase "nature and extent of participatory rights" in Article 11 suggests that participants do not necessarily have to be given TAC allocations. ${ }^{84}$ Despite this absence of prima facie objections against applicants under category (3), concerns existed during the negotiation process leading to the 1995 Fish Stocks Agreement that a situation similar to that under the IWC Convention ${ }^{85}$ could arise, namely, where states opposing harvesting outnumber those in support thereof. ${ }^{86}$

It is not difficult to grasp that, even if applicants under category (3) would have no direct impact on the TAC allocations of existing participants, this could obviously occur indirectly through a more "protectionist" attitude in the RFMM. On the other hand, while the situation under the IWC Convention is special if only due to fact that it concerns whales and not "fish", it is not necessarily unique. The CCAMLR Convention accepts category (3) applicants even though it could be argued that CCAMLR is "something more" than an RFMM as it is explicitly aimed at fostering broader environmental objectives and is also part of the Antarctic Treaty System. ${ }^{87}$ Also worth mentioning is the

83 See also the view by the United States in Annex 6 to NAFO GC Doc. 99/4, that "[a] state could in principle have a real interest in a managed fishery that did not include a direct fishing interest, such as concern for a bycatch species or for the environmental effects of using a particular fishing gear". It continues by arguing that Art. 9(2) of the 1995 Fish Stocks Agreement indicates that "it is possible to have a real interest in fisheries or in the work of a fisheries management organisation or both", and points to the situation under the NAFO Convention (see note 88 below).

84 Cf. Balton, note 64 above at p. 139, n. 97, who, however, consistently refers to "[states] having a legitimate stake in a fishery" instead of "real interest". This could therefore exclude new entrants or states applying under category (3). See also the relevant Arts $10(\mathrm{i})$ and $11(\mathrm{c})$ of the 1995 Fish Stocks Agreement.

85 International Convention for the Regulation of Whaling, Washington DC, 2 December 1946, in force 10 November 1948, 161 UNTS 72; www.ourworld.compuserve.com/homepages/iwcoffice.

86 P. Örebech, K. Sigurjonsson and T.L. McDorman, "The 1995 United Nations Straddling and Highly Migratory Fish Stocks Agreement: Management, Enforcement and Dispute Settlement", (1998) 13 International Journal of Marine and Coastal Law 119.141 at 122.

87 While accession to the CCAMLR Convention is open to "any State interested in research or harvesting activities in relation to the marine living resources to which this Convention applies" (Art. XXIX(1)), membership of CCAMLR is only possible, but not mandatory, when an acceding state is actually "engaged in research or harvesting activities" etc. (Art. VII(2)(b)). 
special situation under the NAFO Convention. ${ }^{88}$ In spite of these examples, applications under category (3) are expected to meet considerable resistance in existing RFMMs or in negotiations that establish RFMMs. ${ }^{89}$

The so-called "new entrants", namely, applications under category (1) and category (2), are at the heart of the controversy. ${ }^{90}$ These applicants could also be in a position to invoke the need to recognise the special requirements of developing states as laid down in Articles 24 and 25(1)(b) of the 1995 Fish Stocks Agreement. As all these applicants will wish a TAC allocation, this will have an immediate impact on the shares of existing participants.

\section{The concept of "real interest" as a bar to participation}

Even though logic seems to indicate that the concept of "real interest" must have a wider purpose of reserving high seas fishing to a certain group or type of states, the question is whether there are arguments that sufficiently justify this wider purpose. One argument that is likely to be used to justify the barring of new entrants to RFMMs or to negotiation processes, is that a TAC which is too fragmented leads to economically ineffective fishing or to the quota being exceeded. While these concerns are understandable, the fear of over-fishing exists of course more generally and should, inter alia, be addressed through efforts aimed at bolstering enforcement. Moreover, increased use of individually transferable quotas (ITQs) and flexible requirements for vessel registration, ${ }^{91}$ will allow multinationals to fish TAC allocations of more than one participating

Membership of the Fisheries Commission, the main management body under the NAFO Convention, is reserved to contracting parties already participating in the fisheries or those that provide satisfactory evidence that they expect to participate in the fisheries within a certain time. Membership of the General Council is open to all contracting parties, although its functions are less focused on fisheries management.

89 As the history of the IWC Convention illustrates, this does not include a change from "within". RFMMs would, for example, have difficulties in dealing with participants that decide not to fish their TAC allocations (see the push for a "use it or lose it" approach in the NAFO Allocation Working Group, led by Japan and Canada and below on the subject of chartering).

90 Orrego Vicuña, note 23 above at p. 208, submits that the requirement of a real interest "can only be taken to mean the conduct of actual fishing operations of significance in the region concerned" and "[t]he fact of having fished in the past or the intention to do so in the future is not enough to qualify for membership or participation under the real interest criteria". He then goes on to argue that states in these categories are in fact new entrants and that these "should be accommodated 'to the extent possible" (p. 210). Orrego Vicuna subsequently treats the matter in the context of Art. 11 and concludes that "in fact the accommodation of new entrants will only be possible when there is a large surplus of the stock and other interests geographically more closely related have been ensured an adequate share of the available resources" (p. 211). Contra Örebech, Sigurjonsson and McDorman, note 86 above at p. 123, who hold that "new entrants must be offered a just and reasonable share of the TAC". See also Division for Ocean Affairs and the Law of the Sea, Office of Legal Affairs, note 69 above at p. 34, para. 113, where it is argued that new entrants "should not in principle be excluded from a share" in the TAC.

See below. 
state, thereby averting economic inefficiency.92 A second argument that may be raised is that once a group of participants exceeds a certain size, this inevitably leads to management problems. ${ }^{93}$ Although this is a valid concern, it should be addressed by restructuring the RFMM and cannot be used to bar the legitimate rights of non-participants.

A third consideration is not a clearly defined argument but rather an underlying resentment against having to accept diminishing shares as a consequence of new entrants. The view that a tradition of fishing activity in specified areas creates preferential treatment or special rights lies at the basis of this resentment. In allocation practice this view has been widely honoured. Entitlement to preferential treatment constituted the core of the 1974 Fisheries Jurisdiction (Merits) cases, where Iceland claimed special coastal state rights, and Germany and the United Kingdom special flag state rights with respect to the same area. The ICJ finally stipulated that coastal state preferential rights imply:
"a certain priority, but cannot imply the extinction of the concurrent rights of other States, and particularly of a State which, like the applicant, has for many years been engaged in fishing in the waters in question, such fishing activity being important to the economy of the country concerned. The coastal State has to take into account and pay regard to the position of such other States, particularly when they have established an economic dependence on the same fishing grounds."94

While acknowledging special coastal state rights and those of "traditional" flag states, the ICJ emphasises that this "cannot imply the extinction of the concurrent rights" of other states. With respect to coastal states, much has obviously changed since 1974 , as they have seen their claims to preferential treatment crystallise in the EEZ regime. ${ }^{95}$ Apart from that, however, there are no immediate reasons to deviate from the main message that the ICJ spelled out in 1974: according preferential treatment to some cannot lead to the annulment of the rights of others. ${ }^{96}$

Due to the absence of well-founded arguments for interpreting or applying the

Cf. Orrego Vicuña, note 23 above at pp. 72-73 and 292-293, who advocates the introduction of market mechanisms in the management of high seas fisheries as an alternative to regulatory mechanisms or "creeping coastal state jurisdiction". However, the NAFO Allocation Working Group presently considers using a minimum allocation (see Annex 11 to GC Doc. 99/4; see also the discussion on chartering on pp. 000-000 below). It could also be argued that multinationals would probably not see the restriction of participation in RFMMs as the main issue or even problematic. Cf. Örebech, Sigurjonsson and McDorman, note 86 above at p. 123.

[1974] ICJ Rep 27-28, para. 62. See also para. 66 and decisions 4(c) and 4(d), at p. 34.

95 Accordingly, "[ $t]$ he interest of the coastal State in obtaining a share of the catch of the resource taken on the high seas is no different than the interest of any other State interested in obtaining a share of the resource" (Division for Ocean Affairs and the Law of the Sea, Office of Legal

Cf. ibid., p. 30 , para. 99. 
concept of "real interest" as a bar to participation in RFMMs per se, restriction of access to high seas fishing will in general be dealt with through TAC allocation. This is not to say that there may not be special circumstances where restriction of access is necessary "to preserve the fish stocks in the interests of their rational and economic exploitation".97 Moreover, the discussion below proposes that the concept of "real interest" may be given effective content by ensuring that flag states comply with their obligations under international law.

In light of the current uncertainty on the meaning of the concept, however, a risk exists that it will be used as a bar to participation. This may have a number of implications. As was already argued, misinterpretation of the concept would give rebuffed parties to the 1995 Fish Stocks Agreement a legitimate right to ignore at least partially the RFMM's management measures.98 Alternatively, states that are uncertain of having a "real interest" could be discouraged from becoming parties to the Agreement.

These two implications proceed from the presumption that the entry into force of the 1995 Agreement, ${ }^{99}$ and its exclusive applicability between parties thereto, is of decisive importance. However, the matter is not so straightforward. Several existing RFMMs already support the taking of measures, collectively or individually, against fishing activities in the regulatory area by non-participants, that undermine the effectiveness of fisheries management. ${ }^{100} \mathrm{Also}$, it cannot be ruled out that there will be so-called "anticipatory implementation" of the 1995 Fish Stocks Agreement and application in conflict with the pacta tertiis principle. It is notable that Article 33(2) of the Agreement in fact obliges states parties to "take measures consistent with this Agreement and international law to deter the activities of vessels flying the flag of non-parties which undermine the effective implementation of this Agreement", 101

In light of these considerations, the RFMM's approach on TAC allocation to new participants is expected to play a central role. ${ }^{102} \mathrm{~A}$ distinction which

971974 Fisheries Jurisdiction (Merits) cases, [1974] ICJ Rep 27, para. 60. This phrase is quoted even though the ICJ explicitly linked it to "some system of catch-limitation and sharing of these resources" and therefore not to a restriction of access.

98 Arguably, the obligations under Art. 17(1) and (2) are not opposable to them and the measures taken by participants under Arts 17(4), 21 and 22 not justified.

99 At the recent First Meeting of the UNICPOLOS (United Nations Open-Ended Informal Consultative Process on Oceans and the Law of the Sea), several (predominantly Latin American) states somewhat surprisingly withheld their support from including in the report of the meeting wording that would call upon states to ratify the 1995 Fish Stocks Agreement. The absence of universal support of the Agreement was mentioned as the ground for this position. At the Sixth Session in the MHLC process, several states also displayed a lack of support for the Agreement despite the fact that it had previously been agreed that the Agreement would constitute the very basis for the negotiations.

${ }^{100}$ See also note 69 above.

101 A similar obligation has been incorporated in Art. 17(4) with respect to states parties to the 1995 Fish Stocks Agreement who are non-participants in an RFMM.

102 See Art. 11 of the 1995 Fish Stocks agreement. 
RFMMs will probably use in this respect is that between states that are already engaged in fishing in the regulatory area and new entrants. States in the first category already experience the impact of the RFMM's measures against nonparticipants, but will not be interested in participating unless they are allocated a share in the TAC which is perceived as equitable. Obviously, what they perceive as equitable will certainly be influenced by the impact of these measures and other national and international pressures to act as a responsible fishing state. ${ }^{103}$ At the same time, participants in an RFMM will have to balance the disadvantage of sharing the TAC among more states, with the advantages of enhanced compliance with the RFMM's management measures and the sharing of conservation efforts. As the fishing activities of these non-participating states are often more or less accepted as a reality and possibly even taken into account in setting the TAC, the emphasis could be more on the advantages of bringing these states into the RFMM. ${ }^{104}$

As already noted above, new entrants stand a smaller chance of joining an RFMM. To improve their position they could decide to enter the fishery but this will of course imply having to face measures against non-participants. The willingness of existing participants to accommodate new entrants is likely to be minimal due to the consequential decrease in their TAC allocations. The TAC allocation to new entrants is therefore expected to be small, if only to discourage further new entrants. And with the current state of world fisheries, the prospects of an increase in allocation after having been accepted as a participant are small. Commencing fishing with the object of improving the chances of participation in an RFMM will not necessarily lead to a higher TAC allocation either. Participants in RFMMs could argue that such fishing activities are only meant to increase leverage in negotiation and do not reflect the "true" stake in the fishery. ${ }^{105}$ This argument could in fact also be used against non-participants who have been engaged in fishing for years but who are suddenly increasing their catches. Be that as it may, new entrants (the "have nots") will often meet considerable opposition from the "haves" if they want a share in high seas fisheries, let alone an "equal" share.

${ }^{103}$ See South Korea's disappointment (see note 154 below) that its membership of the NAFO Commission has not been rewarded with "appropriate quota", and that it may therefore withdraw from NAFO.

${ }^{104}$ See the situation in the CCSBT (note 70 above).

105 The Fourth Session in the MHLC process adopted a resolution, on 19 February 1999 , by which it urged "all States and entities concerned to exercise reasonable restraint in respect of any expansion of fishing efforts and capacity and to apply the precautionary approach forthwith". The resolution adopted at the Fifth Session, on 15 September 1999 (note 81 and pp. 000000 below) stipulates that the future WCPFO Commission "will refrain from consideration of catch history of non-members in the proposed convention area during the period of the interim regime in any future decisions by the Commission on allocation". 
The situation with regard to areas which are not covered by RFMMs or for which negotiation processes are still under way is quite different. States engaged in fishing in these areas do not have to fear measures by other states and their activity would in fact seem to secure their participation in a future RFMM. States with an interest in high seas fishing in general, but who are not fishing in a proposed regulatory area when a negotiation process commences, are expected to try somehow to become involved in this process. Once involved, no impediments exist to them becoming participants, while it considerably increases their chances in TAC allocation should they wish to engage in fishing in the future.

\section{Flag state responsibilities}

The concept of "real interest" is nowhere directly linked to the issues of reflagging and flags of convenience (FOCs), even though those who negotiated the concept might have contemplated this linkage. At any rate, it is worth exploring whether such a linkage could be an option for RFMMs. Shipping companies from traditional maritime states originally used FOCs to evade stringent fiscal, manning and often also safety and environmental requirements. In more recent times, the problem of reflagging has become very pressing in the sphere of fisheries. Fishing operators traditionally or primarily based in states with a large fishing industry often reflag their vessels under foreign flags to secure access to fisheries and/or to evade control of their activities. ${ }^{106} \mathrm{~A}$ recent trend suggests that unscrupulous operators even resort to utilising stateless vessels to evade control. ${ }^{107}$

In case a company wants to secure access to a fishery managed by an RFMM, or to increase its TAC allocation, but the prospects for achieving this are absent in the state where it normally registers its vessels, it may reflag (some of) its vessels to a (or another) state that participates in the RFMM; one that is more sympathetic to the company's interests. If that other state were a non-participant or even a new entrant, the company would obviously be very pleased with that state's request for participation in the RFMM. The "other" state's interests are easy to discern because it generates income from registration and/or from giving access to the fishery. In some cases, these efforts might avoid the state's TAC allocations from being "unused" due to insufficient domestic fishing capacity. ${ }^{108}$

The situation described above always involves a change in register and flag. Depending on the circumstances, however, this change may have a more permanent or a more temporary character. Temporary changes in registers are

\footnotetext{
106 The state in which these companies are primarily based may even have reason to stimulate or to abstain from obstructing this reflagging, e.g. to ensure that a larger amount of catch reaches its markets.

107 See sections 9 and 10 and Annex 6 to the 1999 Report of the NAFO Standing Committee on the Fishing Activities of Non-Contracting Parties in the Regulatory Area (STACFAC).

${ }^{108}$ See note 89 above.
} 
referred to in this article as "bare-boat" chartering. Alternatively, states have the option to make TAC allocations available through "vessel chartering". This does not involve a change in register or flag, and means that the TAC allocation will be caught by a vessel flying a flag other than the state to which the allocation was originally made. It is worth pointing out here that all these alternatives offer real advantages in dealing with small TAC allocations. ${ }^{109}$ But, regardless of whether the chartering arrangement is concluded with a private company or between states, without explicit provision it brings about a fundamental shift in responsibility. This is due to the fact that international law charges flag states with primary responsibility over ships flying its flag.

Concern for reflagging and FOCs arises from the considerable discretion which flag states have in prescribing conditions for registration. This discretion poses a serious threat to reliance on flag state responsibility. While Article 94 of the LOS Convention lays down the key requirement for the flag state to exercise effective jurisdiction and control over ships flying its flag, ${ }^{110}$ Article 91(1) of the LOS Convention empowers flag states to fix the conditions for registration. The latter then goes on to stipulate that "[t]here must be a genuine link between the [flag] State and the ship". This concept of the "genuine link" was developed in response to the growth of FOCs. However, rather than being treated in terms of minimum percentages in national ownership or manning or the presence of local management, the genuine link should be interpreted in terms of ensuring a certain minimum standard in the exercise of effective jurisdiction and control. 111 A state with a "flexible register" should therefore not be given the negative label of FOC, unless it is indeed incapable or unwilling to exercise effective jurisdiction and control. ${ }^{112}$

Notwithstanding the differences between more permanent reflagging, bareboat chartering and vessel chartering, they share the concern that the new flag state may exercise its responsibility less than diligently. This concern could be

${ }^{109}$ See above.

110 Art. 94 elaborates this duty by means of more specific obligations.

111 This was confirmed in the M/V Saiga case (St Vincent and the Grenadines v Guinea) (Judgment of 1 July 1999, www.un.org/Depts/los) before the ITLOS. In para. 83 of its Judgment, the ITLOS concludes that "the purpose of the provisions of the [LOS Convention] on the need for a genuine link between a ship and its flag State is to secure more effective implementation of the duties of the flag State, and not to establish criteria by reference to which the validity of the registration of ships in a flag State may be challenged by other States". See also Art. III(3) of the 1993 FAO Compliance Agreement and Art. 18(2) of the 1995 Fish Stocks Agreement and, more generally, A.G. Oude Elferink, "The Genuine Link Concept: Time for a Post Mortem?" in I.F. Dekker and H.H.G. Post (eds), On the Foundations and Sources of International Law: Essays in Tribute to Herman Meijers (forthcoming); and B. Vukas and D. Vidas, "Flags of Convenience and High Seas Fishing: The Emergence of a Legal Framework" in O.S. Stokke (ed.), Governing High Seas Fisheries: The Interplay of Global and Regional Regimes (forthcoming).

112 The current efforts in tackling illegal, unreported and unregulated (IUU) fishing are illustrative in this respect. The term IUU fishing has obviously been preferred above something like "FOC fishing". COFI is expected to adopt an International Plan of Action on IUU Fishing in 2001 (see www.fao.org/fi/events/events.asp and www.affa.gov.au/ecoiuuf). 
addressed by establishing a certain minimum level of capability in exercising effective jurisdiction and control, for example the state's adherence to and implementation of relevant international instruments, or its compliance record. One way of achieving this would be through the RFMM's terms and conditions for participation, thereby giving effective content to the concept of "real interest". ${ }^{113}$ An alternative would be to define a similar standard as a "qualifying criterion" for TAC allocations. ${ }^{114}$ In a strict and/or formal sense this would not have an impact on the issue of participation and, consequently, could not be regarded as an explicit application of the concept of "real interest". However, as it could imply being barred from engaging in fishing, it would amount to an implicit application. The prohibition on discrimination in Article 8(3) of the 1995 Fish Stocks Agreement naturally requires that these factors cannot be applied in such a manner that new participants would need a higher level of capability in comparison with existing participants.

There can be no doubt that efforts to enhance flag state performance are legitimate, much needed and consistent with the international community's interest in the sustainable use and conservation of living marine resources. In fact, although this section is entitled "Flag state responsibility", the argument is tenable that a linkage between responsibility on the one hand and the concept of "real interest" or allocation on the other hand, could also be applied to coastal states or states in general. This would then result in a much broader assessment of a state's ability to ensure sustainable management of living marine resources. The legitimacy and urgency of these efforts notwithstanding, proper account should be taken of the interrelated issues of fair competition and equitable sharing of the living resources of the high seas.

For states with traditionally strong fishing industries and extensive supporting administrations, "flexible registers" will often be perceived as legal edifices geared towards reaping economic benefits without having to share the (financial) burdens of management in the broadest sense. Seen from that perspective, new entrants appear merely to have a short-term interest in a share of the living resources of the high seas but could not care less about ensuring the long-term sustainability of these resources. Setting minimum performance standards as a condition for participation or allocation would require states to balance revenues with the costs involved in exercising effective jurisdiction and control. This creates a threshold for entering a fishery too soon and contributes to a level playing field in marine capture fisheries.

113 Guidance could be found in the approach towards new entrants under by the 1982 Paris Memorandum of Understanding on Port State Control (signed at Paris, 26 January 1982, in effect 1 July 1982 (the 23rd amendment entered into force on 1 July 2000), text available at www.parismou.org), which involves intensive auditing. See in particular section 8.2 and Annex 5 .

114 See the developments within NAFO and ICCAT below. 
New entrants, especially developing states, undoubtedly see "flexible registers" as a solution to their backlog in this field of enterprise and as an opportunity to share in the living resources of the high seas. It could even be perceived as an alternative to the proposals by Lebanon and Mexico during the Third United Nations Conference on the Law of the Sea (UNCLOS III) to apply the principle of the common heritage of mankind also to high seas living marine resources. ${ }^{115}$ In setting minimum standards of flag state performance, account would have to be taken of the legitimate aspirations of developing states. ${ }^{116}$

Finally, one of the risks of vessel chartering in the context of RFMMs is that the TAC allocation is fished under the responsibility of a flag state with a bad performance record. By only allowing vessel chartering to occur between participants, these risks are not only smaller but can also be directly addressed within the framework of the RFMM. ${ }^{117}$ A subsidiary consideration is quite likely that it prevents non-participants in the RFMM from creating catch histories and, consequently, making claims to participation and allocation. Obviously, this approach does not resolve a possible underlying resentment of participants who would have preferred to see an increase of their own TAC allocations instead of having to "buy" them from other participants. This resentment is not fundamentally different from that in relation to new entrants.

\section{Non-state actors}

The previous section addressed the possible use of the concept of real interest to bar flag states that are incapable of exercising effective jurisdiction and control from participating in RFMMs. This section examines the possible relevance of activities by non-state actors with regard to this concept. For example, a state could argue that although it has no flag vessels operating in the (proposed) regulatory area, its nationals or companies have strong interests in vessels that are (but that fly another flag), and that it should on that basis be entitled to participate in an RFMM. ${ }^{118}$

This role for non-state actors is hinted at through phrases such as "States whose nationals fish" and "States fishing on the high seas", as incorporated in Articles 5, 7, 8 and 16 of the 1995 Fish Stocks Agreement. Conversely, other provisions in the Agreement use terminology that refers much more clearly to

115 See Orrego Vicuña, note 23 above.

116 See, for instance, Art. 25(1)(b) of the 1995 Fish Stocks Agreement.

117 See the position taken within the SEAFO process and in NAFO below.

$118 \mathrm{~A}$ reference to joint ventures is included in the Record of Proceedings of the Third Meeting in the SEAFO process. The Meeting agreed that "clarification of the flag status of fishing vessels with connections to Iceland would establish the basis for continuing the invitation to Iceland" (p. 3, para. 4(a)). This phrase is not very clear and can be interpreted in several ways. However, the fact that Iceland was, and is, involved in joint ventures with Namibian companies apparently never played a real factor in Iceland's eligibility to participate in the SEAFO process or the concept of "real interest". Prior to the Fourth Meeting, catch statistics clearly revealed Iceland's involvement as a flag state and Iceland participated in the SEAFO process from the Fourth Meeting onwards. 
states in their capacity as flag state. ${ }^{119}$ The question that must therefore be addressed is whether the clauses in Articles 5, 7, 8 and 16 are meant to look beyond the "flag state veil", namely, to foreign involvement in the flag state's fishing industry as a basis for entitlement to certain rights.

Prima facie this lack of uniformity in terminology must presumably serve some purpose. However, the previous section's conclusions on the correct meaning to be accorded to the concept of the genuine link imply that there is no right to "pierce the flag state veil". ${ }^{120}$ It is worth pointing out as well that the LOS Convention does not consistently use the same terminology either, and the argument of a right to pierce the flag state veil has not received any support under that Convention. ${ }^{121}$ It would also seem to be virtually impossible to ensure objectivity in assessing foreign (commercial) interests in the fishing industry of a flag state. Taking such interests into account in relation to the concept of "real interest" would have consequences that extend far beyond the scope of fisheries management. Finally, as prospects of agreeing on a definition of the genuine link look bleak, ${ }^{122}$ it is noteworthy that growing support exists for exercising control over foreign involvement in a flag state's fishing industry by means of jurisdiction based on the personality principle. ${ }^{123}$ After the extension of coastal

${ }^{119}$ E.g. Arts 14, 17(2), 18(3) and 19(1) ("vessels flying their [its] flag") and Art. 18 ("A State whose vessels fish on the high seas").

$120 \mathrm{Cf}$. the statement by the EC upon signature of the 1995 Fish Stocks Agreement (Interpretative Declaration No. 3), which reads: "The $[E C]$ and its Member States understand that the term 'States whose nationals fish on the high seas' shall not provide any new grounds for jurisdiction based on the nationality of persons involved in fishing on the high seas rather than on the principle of flag State jurisdiction."

${ }^{121}$ Like Art. 7 (1) of the 1995 Fish Stocks Agreement, the reference to nationals in Art. 116 of the LOS Convention is merely a way of formulating and according the right to fish on the high seas. This right cannot be exercised other than under the nationality of a flag State (see also Arts 92(2) and 93 and the way in which the right of innocent passage in Art. 17 of the LOS Convention is worded). The use of "nationals" in Arts 61(5) and 62(3) and (4) of the LOS Convention serves a different purpose still.

122 United Nations General Assembly Resolution A/54/32, of 18 November 1999: "8. Calls upon the International Maritime Organization [IMO], in co-operation with the Food and Agriculture Organization of the United Nations, regional fisheries management organisations and arrangements, and other relevant organisations, and in consultation with States and entities, to define the concept of the genuine link between fishing vessels and the States in order to assist the implementation of the [1995 Fish Stocks Agreement]." Discussion within IMO (see IMO Docs MSC 71/10/1, MSC 71/23, paras 10.20-10.25, MEPC 43/9/3, FSI 7/14, paras $9.1-9.11$, FSI $8 / 6$ and FSI 8/INF.6) has so far not led to a definition of, or even support for, the concept of a genuine link which deviates from the above-mentioned ITLOS Judgment, although special reference is often made to Art. 91 of the LOS Convention exclusively (IMO Doc. FSI 8/6, para. 17(b); but see para. 12). See also the conclusion of ITLOS in the $M / V$ Saiga case on the aspect of nationality of claims (note 111 above, paras 103-109).

123 Art. 13(6)(a) of the SEAFO Draft Convention (Sixth Meeting) includes an obligation that "each Contracting Party shall, to the greatest extent possible, take measures, or co-operate, to ensure that its nationals fishing in the Convention Area and its industries comply with the provisions of this Convention". This clause replaces the reference to "vessels owned or controlled by its nationals" included in the previous draft (see also the Report of the Fifth Meeting). Art. 23(5) of the WCPFO Draft Convention (Sixth Session) contains an integrated version by referring to 
state jurisdiction and the increased use of port state jurisdiction, this signifies a further step in addressing the serious shortcomings of flag state jurisdiction. Similar to the situation in vessel-source pollution, these steps are presented as complementary exercises of jurisdiction that are not to be interpreted as affecting the flag state's primacy.

The issue of non-state actors also arises in relation to so-called "entities" and "other fishing entities whose vessels fish on the high seas" as referred to in the 1995 Fish Stocks Agreement. ${ }^{124}$ Article 1(2)(b)(i) provides that the Agreement applies mutatis mutandis "to any entity referred to" in Article 305(1)(c), (d) and (e) of the LOS Convention "and which becomes a party to this Agreement, and to that extent 'States Parties' refers to those entities". ${ }^{25}$ Article 1(3) also stipulates that the Agreement applies mutatis mutandis to "other fishing entities" etc., but omits any reference to their becoming parties to the Agreement or that "States Parties" should refer to these as well. This sufficiently indicates that "fishing entities" referred to in Article 1(3) are intended to be distinct from "entities" referred to in Article 1(2)(b). ${ }^{126}$ Even though the former category of

cont.

"nationals, and fishing vessels owned or controlled by its nationals fishing in the Convention Area". The working draft of 17 April 2000 at the Sixth Session contained far more controversial uses of the clause "owned or controlled by" in Art. 25(2) and (4), but these did not find enough support. See also Art. 15(2) of the CCSBT Convention and the CCSBT Action Plan, para. 5 (note 70 above). The "Policy to Enhance Co-operation Between CCAMLR and NonContracting Parties", adopted at the 18th Meeting of CCAMLR, does not contain a reference to nationals. The Australian proposal to this effect was strongly opposed, predominantly by the EC (the text of the Policy is available at www.ccamlr.org; see also CCAMLR-XVIII/BG/51, para. 2(j); SCOI 99/18, para. 2(b)(iv); and CCAMLR-XVIII/BG/52).

124 Arts 1(2)(b)(i), 1(3) and 17(3). See also sections 1.2 and 4.1 of the 1995 FAO Code of Conduct and the Order in the Southern Bluefin Tuna (Provisional Measures) cases, the latter of which refers to fishing entities in provisional measure ( $f$ ).

125 See the similarity with Art. 1(2)(2) of the LOS Convention, which also uses "entities". Art. 305 permits these entities to sign the LOS Convention and, through ratification or accession (Arts 306 and 307 of the LOS Convention), become states parties. Art. 1(2)(b)(ii) of the 1995 Fish Stocks Agreement refers to the third type of entity, namely, international organisations as referred to in Art. 1 of Annex IX to the LOS Convention.

${ }^{126}$ The word "other" before "fishing entities" in Art. 1(3) seems to imply the existence of fishing entities that do not fall under Art. 1(3), for instance the entities in Art. 1(2)(b) (e.g. R.R. Churchill, "The European Community and Its Role in Some Issues of International Fisheries Law" in E. Hey (ed.), Developments in International Fisheries Law (Kluwer Law International, 1999), pp. 533-573 at pp. 572-573, consistently refers to the EC as a "fishing entity"). This confusing drafting should not distract from the basic purpose of Art. 1(3), namely, to create a special category of entities that cannot become a party to the Agreement, but which should for all other purposes be treated as similar to states, as qualified by the word mutatis mutandis. Rather than regarding "fishing entities" as a new concept, it is preferable to treat "fishing entities" referred to in Art. 1(3) as a special category of entities. See also ICCAT Resolution 9717. 
entity is not used in the LOS Convention, it is widely regarded as being incorporated for the specific purpose of Taiwan (Republic of China). ${ }^{127}$

One commentator has argued, however, that "this broad definition could in the future give place to other claims in this context, including eventually private and non-governmental organisations". ${ }^{128}$ The issue shows some similarities with that of piercing the flag state veil, as discussed above. A loosely formulated definition would seem insufficient to argue that the 1995 Fish Stocks Agreement intends to bestow rights and obligations on non-state actors on a (somewhat) similar footing as states. Such a contention would be inconsistent with the framework character of the 1995 Fish Stocks Agreement and its relationship with the LOS Convention. ${ }^{129}$ Obviously, this does not prevent states from mutually agreeing to admit such non-state actors and/or granting them certain participatory rights.

\section{State practice relevant to the concept of real interest}

This section discusses the main developments in state practice relevant to the concept of "real interest" that are currently taking place within the SEAFO process (the establishment of the South East Atlantic Fisheries Organization), the MHLC process, NAFO (Northwest Atlantic Fisheries Organization), ICCAT (International Commission for the Conservation of Atlantic Tunas) and NEAFC (North-East Atlantic Fisheries Commission). It is certainly not excluded that other relevant state practice exists as well. ${ }^{130}$

${ }^{127}$ Art. 43 of the WCPFO Draft Convention (Sixth Session) defines "fishing entity" as "a separate customs territory possessing full autonomy in the conduct of its external commercial relations". Rather than becoming a contracting party to the Convention, the draft still merely envisages that a fishing entity "may, by an instrument in writing, affirm its acceptance of the regime established by this Convention" (Art. 43). Whether Taiwan accepts not being a contracting party, even though offered membership of the Commission (Art. 1(2)), remains to be seen. However, under the SEAFO Draft Convention (Sixth Meeting), "fishing entities" are not offered membership of the Commission but are asked to co-operate fully with the organisation (Art. 22(4)). Art. 1(i) simply defines "fishing entity" as "any fishing entity referred to in" Art. 1(3) of the 1995 Fish Stocks Agreement. Similar discussions are taking place within the CCSBT. Orrego Vicuña, note 23 above at p. 139. See also p. 213.

129 See Art. 4 of the 1995 Fish Stocks Agreement.

${ }^{130}$ For instance, the 2000 Arrangement between the Government of Australia and the Government of New Zealand for the Conservation and Management of Orange Roughy on the South Tasman Rise (signed for New Zealand on 17 February 2000 and for Australia on 25 February 2000; the Agreement takes effect on 1 March 2000) provides in paras 30 and 31 that "the Parties will jointly consider" participation by "third countries which have a real interest". Also, Australia, New Zealand and South Africa met in Hobart, Tasmania, on 8 and 9 November 1999 , for an informal consultation on the conservation and management of an orange roughy stock situated close to Broken Ridge on the high seas in the southwestern part of the Indian Ocean. An Australian letter distributed after the meeting contains the following passage: "It was accepted that any agreement must involve all parties with a real interest in the fishery. It was also accepted that the arrangements should be transparent and open to new entrants with a demonstrated real interest in the fishery. However, Australia would wish to ensure that 'real interest' can be adequately substantiated" (letter by G. Rohan, Australian Fisheries Management Authority (AFMA), of 17 December 1999). 


\section{The SEAFO process}

The SEAFO negotiation process was initiated by the four relevant coastal states, namely, Angola, Namibia, South Africa and the United Kingdom (in respect of St Helena and its dependencies). At first they invited only the European Community (EC), Japan, Norway, Russia and the United States, as these states were "identified as having distant water fishing interests in the region", even though not all were at that time actually engaged in fishing in the envisaged Convention Area. At a later stage, Iceland, Poland, South Korea and Ukraine were also invited, based on FAO fishing data and the desire to establish an open organisation. ${ }^{131}$ In the early stages of the negotiation process, an attempt was made to agree on a definition of the concept of "real interest" and actually to limit accession to states, entities and regional economic integration organisations with a real interest. ${ }^{132}$ However, due to a failure to resolve different interpretations, the concept of "real interest" does not appear in the main body of the draft Convention agreed to at the Fourth Meeting, or in later versions. The preamble to the draft that came out of the Sixth Meeting (May 2000) nevertheless contains the paragraph: "DESIRING co-operation with the Coastal States and with all other States and Organisations having a real interest in the fishery resources of the South East Atlantic Ocean to ensure compatible conservation and management measures." It is submitted that the inclusion of the concept amounts to recognition of its significance, even though the Convention itself refrains from explicitly including it. ${ }^{133}$

Draft Article 25(1) (Sixth Meeting) provides that the Convention shall be open for signature by all participants in the negotiation process and by "all states and regional economic integration organisations whose vessels fish, or have fished in the Convention Area, for fishery resources covered by this Convention, in the [three] years preceding the adoption of the Convention". This timespan relates to the full period during which the negotiation process took place. These states or regional economic integration organisations (REIOs) that did not participate in the process are thus offered the same position as those that did. Fishing activity in the period preceding the SEAFO process is not regarded as sufficient. This corresponds with draft Article 26(1) which allows accession to the Convention by coastal states, and all other states and REIOs "whose vessels fish in the Convention Area for fishery resources by this Convention". Applicants under category (1), as defined above, i.e. flag states that fished in the regulatory area previously and want to resume fishing, are thus barred from accession, unless

131 Record of Proceedings, Fourth Meeting, Brief Summary of the SEAFO Process Prepared by the UK Chair. The meeting also noted that "statistics on vessels fishing in the Convention Area have provided the basis for invitations to States other than Coastal States to join the process, as required by the UN Fish Stocks Agreement" (Record of Proceedings, Fourth Meeting, Attachment 7).

132 See Arts 4 and 25 of the SEAFO Draft Convention (Third Meeting).

133 See Explanatory Note Sixth Meeting, para. 33. 
they first resume fishing which implies being confronted with measures against non-participants. ${ }^{134}$ They are therefore clearly in a less comfortable position compared to those states that participated in the SEAFO process without a catch history but that were nevertheless "identified as having distant water fishing interests in the region". Future TAC allocations will be dealt with in the framework of draft Article 19 (Sixth Meeting), which is entitled "Fishing Opportunities".

Finally, with respect to the issue of chartering, it is noteworthy that Article 13(6)(b) of the SEAFO Draft Convention (Sixth Meeting) provides that "[f]ishing opportunities granted to Contracting Parties by the Commission, shall be exercised exclusively by vessels flying the flag of Contracting Parties". While thus accepting vessel chartering, this approach ensures that responsibility for vessels engaged in relevant fishing activity remains among the contracting parties.

\section{The $M H L C$ process}

The initial invitations to participate in the MHLC process were sent out to "States and entities with an interest in the highly migratory fish stocks in the region ... either as full participants, or as observers". ${ }^{135}$ At the end of the Sixth Session (April 2000) a total of 29 states and entities were full participants, ${ }^{136}$ and two states and one REIO, namely, Ecuador, the EC and Mexico, were observers. Unlike in the SEAFO process, no consideration was given to incorporating the concept of real interest in the draft texts, not even in the preamble. However, in assessing a state's request to become a full participant or observer in the MHLC process or in the Preparatory Conference pending the Convention's entry into force, the concept of real interest has been repeatedly invoked. The Conference's decisions and its motivation either to accept or to deny requests to participate fully or as observers, must also be treated as practice in relation to the concept.

Canada merely participated as observer in the Second and Third Sessions. At the Fourth Session (February 1999), however, it managed to secure the support of the Member States of the South Pacific Forum Fisheries Agency (FFA) for its wish to become a full participant. A statement made by Vanuatu on behalf of the FFA Member States supporting Canada's full participation was carried by the Conference, ${ }^{137}$ despite the fact that Canada never directly addressed the Conference with a formal request. The reasons for admitting Canada as full

134 Draft Art. 4 referred to in the text accompanying note 132 above, however, still reflected uncertainty on this issue, as the phrase "whose vessels are [or have been] fishing [fish]" indicates. MHLC Chronicle, Annex 8 to the Report of the Fifth Session.

136 Australia, Canada, China, the Cook Islands, the Federated States of Micronesia, Fiji, France, French Polynesia, Indonesia, Japan, Kiribati, the Marshall Islands, Nauru, New Caledonia, New Zealand, Niue, Palau, PNG, the Philippines, the Republic of Korea, Samoa, the Solomon Islands, Chinese Taipei, Tonga, Tuvalu, the United Kingdom (in respect of Pitcairn, Henderson, Ducie and Oeno Islands), the United States, Vanuatu and Wallis and Futuna. Canada was an observer at the Second and Third Sessions and the United Kingdom at the Fifth Session (see below in main text).

${ }^{137}$ Report of the Fourth Session, para. 7. 
participant are presumably its relatively small fishing activities in the envisaged regulatory area, its support for the conservation and management of Pacific tuna and the fact that it is a Pacific country. ${ }^{138}$ The Conference's "decision" did not necessarily meet with unanimous support, however. The opening statement made by Japan at the Fifth Session clearly reveals both its surprise at being confronted with the Vanuatuan statement, its discontent for not being given an explanation for the reasons for admission, and the lack of transparency which this caused.

The EC and Mexico were both accepted as observers at the Fourth Session and their participatory status has not changed since. At the time, no explanation for the acceptance of their observer status was offered. Not that such an explanation would actually have been necessary, but it contrasts with Ecuador's situation (below). In its opening statement at the Fourth Session, the EC maintained that it had a real interest in the sense of Article 8 of the 1995 Fish Stocks Agreement and that the future WCPFO should be open to all that have a real interest. A number of arguments seek to substantiate this position. Noteworthy is the cautious way in which reference is made to the modest (relevant) fishing activities by Community fishing vessels. ${ }^{139}$ The Mexican delegation did not make a statement at the Fourth Session but its statement at the Fifth Session largely pursues the same approach as the EC. While its position is naturally substantiated by different arguments, Mexico could also not rely on current fishing activities of relevance, even though it had engaged in such activities in the past.

By the Fifth Session (September 1999) these requests for status as full participant had led to considerable concern about the direction in which the MHLC process was developing. The opening statement by Papua New Guinea (PNG) starts off with a reconfirmation of its commitment to the objectives of the MHLC process. For PNG this implied a need "to co-operate with existing foreign fishing fleets in our region" 140 but it also went on to observe that "we are particularly concerned that our interests as resource owners are being increasingly diluted". The statement then refers to proposals to move the boundary of the Convention Area northwards, which is feared to lead to an "ever increasing number of coastal States and countries declaring a real interest in our region". The delegation of PNG "therefore supports calls to impose a moratorium on new entrants until the Commission is properly established. Failure to take this bold move may see further dilution of our interests and we

${ }^{138}$ This presumption is based on Tuna Fishery in the Pacific Ocean: The Canadian Interest (Informal Non-Paper, Fourth Session); and the Canadian Statement at the Fifth Session. The text of the Vanuatuan statement was unavailable to the author. It should be noted, moreover, that due to ongoing considerable differences in view on the geographical extent of the Convention Area, an assessment of catch records is rendered extremely difficult.

139 The statement, inter alia, mentions that " $[t]$ he Community has initiated exploratory demarches in view of the conclusion of a fisheries agreement with certain pacific island states in the area which could be covered by the future organisation" and that "Community fishing vessels are already active in the central Pacific" (Annex 3, Report Fourth Session).

140 Emphasis added. 
are most likely not to reach consensus on the most critical issues to conclude an appropriate Convention." A large number of participants shared these concerns and, on 15 September 1999, the Conference adopted a resolution by which the participants in the MHLC process:

"1. Decide that the number of the participants in MHLC should not be increased;

2. Decide further that requests for participation in MHLC will not be entertained until the draft Convention enters into force;

3. Agree to consider applications for observer status as appropriate;

4. Agree further that in future members of the proposed Commission for the Conservation and Management of Highly Migratory Fish Stocks in the Western and Central Pacific ('the Commission') will refrain from consideration of catch history of non-members in the proposed Convention Area during the period of the interim regime in any future decisions by the Commission on allocation."

It is submitted that this resolution addresses, as PNG puts it, the "dilution of interests" in two ways, both of which can also be discerned in PNG's statement. The first is to ensure that the already difficult negotiations are not further complicated by a larger number of participants. A broad consensus exists that the future WCPFO Convention should above all reflect the interests of small Pacific island states and an increase in participants that do not belong to this group would obviously threaten this objective. The second element is contained in the resolution's last paragraph (4) and can only be interpreted as an attempt to freeze the status quo with regard to future TAC allocation. The implications for nonparticipants are obvious. However, the resolution's preamble also refers to the resolution of 19 February 1999, adopted at the Fourth Session, which, inter alia, urges "all States and other entities concerned to exercise reasonable restraint in respect of regional expansion of fishing effort and capacity and to apply the precautionary approach forthwith". On the one hand, this reflects a logical concern for over-exploitation in a phase when the RFMM is still being established. On the other hand, one obvious reason for increasing fishing effort would be an attempt to improve the chances of obtaining higher TAC allocations by the future WCPFO Commission. In this latter light, the two resolutions address the same issue. It is nevertheless submitted that the freezing of the status quo effectively makes new entrants dependent on the goodwill of full participants in the MHLC process.

The next significant development took place in December 1999, only a few months after the end of the Fifth Session, when a Spanish company concluded a fishing access agreement with Kiribati ${ }^{141}$ The agreement gives access to the

${ }^{141}$ This raises questions on the behaviour of Kiribati, the EC and the Spanish company in relation to the call incorporated in the resolution of 19 February 1999 to exercise reasonable restraint in expansion of fishing effort. 
maritime zones of Kiribati to a total of 14 of the company's vessels. A complicating factor is that only five of these vessels fly the Spanish flag, while five are registered in Ecuador, four in Guatemala and one in Panama. Although this agreement reinforces the EC claim of a real interest by transforming it into a "state fishing" pursuant to paragraphs (3) and (5) of Article 8 of the 1995 Fish Stocks Agreement, at the same time it also strengthens the potential claims of three new states. The concerns expressed in PNG's statement made at the Fifth Session proved justified when Ecuador made a request to become an observer at the MHLC process prior to the Sixth Session. Guatemala and Panama made no such request, but this might of course change at a later stage.

At the Sixth Session (April 2000), the EC repeated its previous position but added that its claim to a real interest had become bolstered due to the "private arrangement" with Kiribati. The EC also specifically requested to become a full participant in the interim regime of the MHLC process, namely, the Preparatory Conference. ${ }^{142}$ This request was merely dealt with in an implicit manner by the Conference's resolution of 19 April 2000, which gives observers in the MHLC process only the right to participate as observers in the Preparatory Conference. ${ }^{143}$ While the Conference was thus unwilling or unable to deal with the EC's request in an explicit manner, and to motivate its denial, the FFA Member States nevertheless felt compelled to issue a statement on its behalf. In the first part of the statement it is basically argued that the moratorium contained in the resolution of 19 September 1999 should continue and that the EC's observer status would not "limit unduly its ability to contribute towards the work" of the Preparatory Conference. This part thus relates to first element of the resolution of 19 September 1999 discussed above. The second part of the statement reads as follows:

"We are concerned that if the [EC] were to be allowed to participate fully in the Preparatory [Conference] it would in effect be accorded status equal to those who have been involved with this process from the outset or who have otherwise been admitted to participation on substantive grounds.

This would inevitably lead to pressures to become a party to the Convention on the same basis and provide an opening for others, including States that have, or may soon have, flag vessels fishing in the region, from making claims for participation. We believe this could further undermine the intent of the moratorium.

... [W]e also feel it is somewhat premature to make a decision on the issue of additional participants to the Preparatory [Conference] at this

142 See the letter of 10 April 2000 by S. Smidt, Director General of DG XIV (Fisheries) to Chairman S. Nandan of the MHLC process and the opening statement of the EC at the Sixth Session.

143 Para. 1 of the "Resolution Establishing a Preparatory Conference for the Convention on the Conservation and Management of Highly Migratory Fish Stocks in the Western and Central Pacific Ocean" (Annex 6, Report of the Sixth Session). 
stage. We believe it would be more appropriate to consider carefully the grounds for granting participation in the Commission, based on the concept of a 'real interest' provided for in the $[1995$ Fish Stocks Agreement], which needs further elaboration in relation to the MHLC process. In this regard, we would suggest that the matter of criteria for new participants be firstly discussed and agreed to at the Preparatory [Conference] prior to making decisions on the [EC] application for participation." 144

These paragraphs aptly sketch the dilemma faced by the full participants in the MHLC process. At the same time, in light of the resolution of 19 September 1999, the decision to resolve the issue at a later stage is certainly not unfavourable to the full participants. This is because, as has been pointed out above, the "intent of the moratorium" is twofold: a more general concern for over-exploitation and a specific concern that states increase or commence fishing effort in order to bolster claims to TAC allocations. Again, while it must be admitted that Article 8(5) of the 1995 Fish Stocks Agreement, which deals with negotiations to establish RFMMs, does not explicitly refer to the concept of "real interest", this is not necessarily a convincing argument. ${ }^{145}$

The contrast between the failure of the EC to achieve its objectives and Canada's success is striking. This can undoubtedly be attributed to a number of reasons, including the unfortunate timing combined with the effects of the private arrangement but perhaps also the EC's inability to exert sufficient and effective pressure on full participants in the MHLC process.

Ecuador's request for observer status led the Conference to agree more in general that:

" $[R]$ equests for observer status by States may be considered provided it is understood that such observer status shall not be treated as an entitlement to become a party to the Convention nor shall it be used as a basis to justify future participation in the Commission or as a basis to seek a future allocation. Subject to the approval of the Conference, observers may be permitted to make statements of a general nature on matters of interest to them and to circulate written submissions.

With respect to the request by Ecuador, the Conference agreed that the request by Ecuador for observer status in the Conference would be allowed on the basis that Ecuador is a State with a Pacific coastline with fishing interests in respect of the same stocks in an area adjacent to the proposed Convention Area."146

144 On file with author.

145 See the discussion above.

${ }^{146}$ Report of the Sixth Session, paras 5 and 6. 
This general position evidently builds on and elaborates the position already taken in the two resolutions adopted in 1999 and the statement made on behalf of the FFA Member States with regard to the request by the EC.

Pursuant to the draft text which came out of the Sixth Session, states and territories which participated as full participants in the MHLC process, and any entity referred to in Article 305 (1)(c), (d) and (e) of the LOS Convention, are entitled to become contracting parties without any further qualification. 147 However, Article 35(2) envisages that the Commission "may, by consensus, invite other states and regional economic integration organisations, whose nationals and fishing vessels wish to conduct fishing ... in the Convention Area to accede to this Convention". As any one future Member of the Commission can in fact obstruct consensus, this contrasts sharply with the intention to create an "open organisation" by the SEAFO process, as reflected in draft Article 25(1) (Sixth Meeting).

This different approach is probably influenced by a variety of factors. Prominent among these would seem to be the particular characteristics of the fisheries in the proposed Convention Area. As the various tuna species spend most of their time within the maritime zones of coastal states, it is not economically viable to engage in fishing without access to these maritime zones. Unlike the situation in many other RFMMs, limiting effort to high seas fishing is therefore not a real option. As even the United States agrees by now that in principle coastal states do not have an obligation to give access to their maritime zones (also with respect to highly migratory species), this gives these states considerable leverage. It could even be argued that the relevant coastal states effectively control high seas fishing or at least have the potential to do so. The extent to which these coastal states will be able to retain this leverage within the future WCPFO therefore seems to be the key factor for the future character of this organisation. These issues will not be resolved by the MHLC process and it is not unlikely that the Commission, once instituted, will still need considerable time to agree on them.

\section{NAFO}

At the 19th Annual Meeting of the NAFO Fisheries Commission, in 1997, the "Working Group on Allocation of Fishing Rights to Contracting Parties of NAFO and Chartering of Vessels Between Contracting Parties" (NAFO Allocation Working Group) was established. In the Working Group's terms of reference, ${ }^{148}$ no explicit mention is made of non-contracting parties, but at the first Meeting of the Working Group in 1998, widespread agreement existed that the situation of "future new members" should also be addressed. Consequently,

${ }^{147}$ Arts 34 and $35(1)$. The reference to "any entity" was previously included in para. (2) of this provision.

148 Annex 2 to GC Doc. $99 / 4$. 
the concept of "real interest" appeared prominent in the guidelines for future discussions. ${ }^{149}$ The very fact that the Working Group would be addressing two issues, allocation of fishing rights and chartering, already indicates their relatedness. The opening statements made by Canada and the EC at the first Meeting both emphasise this point. ${ }^{150}$ These and other statements also expressed concern that the discussion could destabilise current NAFO allocation practice and thereby potentially the entire organisation.

The concept of "real interest" appeared as a separate item on the agenda of the Second Meeting of the Working Group (1999) and was specifically addressed in a paper by the United States. ${ }^{151}$ Extensive discussions did not lead to a common understanding of the concept, but it was agreed that this was not necessary to consider a strategy to guide the expectations of new participants. Such a strategy was based on a proposal by the United States and led to the adoption of a "Draft General Council Resolution to Guide the Expectations of Future New Members with Regard to Fishing Opportunities in the NAFO Regulatory Area". After some minor changes, the General Council eventually adopted this resolution in September 1999.152 While paragraph (1) states that "NAFO is an open organisation", this is followed in paragraph (2) by:

"Should any new member of NAFO obtain membership in the Fisheries Commission, in accordance with Article XIII(1) of the Convention, such new members should be aware that presently and for the foreseeable future, stocks managed by NAFO are fully allocated, and fishing opportunities for new members are likely to be limited, for instance, to new fisheries (stocks not currently allocated by TAC/quota or effort control), and the 'Others' category under the NAFO Quota Allocation Table."153

The message that this resolution seeks to convey is perfectly clear: new participants, including new entrants, should expect only minimal TAC allocations. This will certainly not be an incentive for such states to become contracting parties. ${ }^{154}$ Interestingly enough, the original proposal by the United States contemplated broader sharing if regulated stocks were to recover, but the majority took the view that the "benefits of recovered stocks should accrue to current NAFO members only, in recognition of their restraints and contributions

${ }^{149}$ Annex 9 to GC Doc. $98 / 2$.

150 Annexes 3 and 7 to GC Doc. $98 / 2$.

151 Annexes 5 and 6 to GC Doc. $99 / 4$ respectively.

152 Annex 13 to the Report of the 21st General Council Meeting (GC Doc. 99/9).

${ }_{153}$ See also note 88 above.

154 On the other hand, during 1998 and 1999, relatively little fishing activity by non-contracting parties to the NAFO Convention appears to have taken place in the NAFO Regulatory Area (see GC Doc. 99/9, paras 4.1-4.6 and GC Doc. 98/7, paras 4.1-4.4). But see the statements by South Korea in Annex 5 to GC Doc. 98/2 and Annex 12 to GC Doc. 99/9, who is dissatisfied with the current TAC allocation of 69 tons as it was fishing an average 9,000 tons before acceding to the NAFO Convention. 
to conservation". ${ }^{155}$ The irony is of course that previously these states also enjoyed the benefits of extensive fisheries, which ultimately led to their collapse. Irresponsible management in the past thereby provides a justification for minimising allocations to new participants in the present and future.

The future expectations strategy does not exclude new participants from acceding to the NAFO Convention but seeks to resolve the dilemma of increased numbers of participants through TAC allocation. In principle, therefore, this strategy approaches the issue in accordance with the propositions made above. On the other hand, the expected minimal TAC allocations for new participants will undoubtedly raise concerns of equity while some may even question their consistency with international law. ${ }^{156}$ This inevitably has an impact on the readiness of new participants to accede to the NAFO Convention. The lion's share of the TAC in the NAFO Regulatory Area is thus effectively reserved for a small group of states and shielded from potential new participants through the future expectations strategy and the NAFO measures against non-participants.

Apart from fishing under the "Others" category, ${ }^{157}$ new fisheries are the only other chance for new participants. It is interesting to note that the discussion of the "Development of a broad strategy of allocating future fishing opportunities for stocks not currently allocated" makes a distinction between "qualifying criteria" and "allocation criteria". ${ }^{158}$ One of the "qualifying criteria" is listed as "future new members 'in good standing" (co-operative in accordance with relevant international agreements such as [the LOS Convention and the 1995 Fish Stocks Agreement] and consistency with NAFO measures)." Potentially, this notion of "qualifying criteria" could to some extent operate as an implicit application of the concept of "real interest". 159 The outcome of the third and/or later meetings of the Allocation Working Group might shed more light on this. ${ }^{160}$

The Second Meeting of the Working Group was unable to finalise the discussion on vessel chartering with the adoption of the "Draft Resolution Concerning the Chartering of Vessels Flying the Flag of a Contracting Party in

${ }^{155}$ Section 5, GC Doc. 99/4. See the minimal percentage (10 per cent) of recovered stocks that Denmark envisages to be added to the "Others" category, and the observation by Canada that the strategy "will not affect existing fishing rights of Contracting Parties" (Annexes 8 and 3 to GC Doc. 99/4 respectively).

156 This argument would be based on Art. 116 of the LOS Convention and/or Art. 1(1)(b) of the 1995 Fish Stocks Agreement.

157 NAFO contracting parties who are members of the Fisheries Commission, but who are not allocated quotas, can fish under the "Others" quotas. Fisheries under these quotas are closed when the quotas are expected to have been reached (see Part 1.A.3(b) of the NAFO Conservation and Enforcement Measures (note 164 below)).

158 Annex 11 to GC Doc. $99 / 4$.

159 How this would work exactly is difficult to say. It is notable that other "qualifying criteria" are very similar to the allocation criteria listed in Art. 11 of the 1995 Fish Stocks Agreement.

160 The Third Meeting took place in March 2000, but the report was not available at the time of writing. 
the Regulatory Area". ${ }^{161}$ Nevertheless, "the meeting did not oppose a pragmatic solution in principle if it were based on the premise that charters would be limited to extraordinary circumstances and in time to no more than two and possibly three years and that a bilateral agreement between the Contracting Parties would address the enforcement responsibilities between the parties involved". 162 The discussions in the General Council in 1999 also continued to show considerable differences in opinion and the draft resolution was referred to the Fisheries Commission and then to STACTIC (Standing Committee on International Control). ${ }^{163}$ Subsequently, the Fisheries Commission adopted a new Part I.B entitled "Chartering Operations" in the NAFO Conservation and Enforcement Measures, and amended Part III.D on "Notification of Fishing and Processing Vessels" with a subsection on "Vessels temporarily flying the flag of a Contracting Party (bare boat charter)". ${ }^{164}$

What is notable about these new measures on vessel chartering and bare-boat charters is that the former stipulates that "Contracting Parties shall limit such transfers to one fishing vessel per year and for a limited duration not exceeding 6 months". As Denmark noted in the discussion in the Fisheries Commission, this is considerably more restrictive than was expressed during the discussions in the Allocation Working Group and the General Council. Denmark nevertheless agreed with adoption, partly because as a pilot project it would only apply to the year 2000 and would be subject to review thereafter. ${ }^{165}$ Vessel chartering can only take place between contracting parties and is also subject to adoption through a mail vote in accordance with Article XI(2) of the NAFO Convention. ${ }^{166}$ Finally, the principle of flag state responsibility is confirmed, in addition to upholding the obligations of the contracting party to which the quota was originally allocated. No substantive limitation was imposed on bare-boat charters, however. ${ }^{167}$ These differences in position reflect the concern of NAFO contracting parties for the issue of flag state responsibility, as this constitutes the main distinction between vessel chartering and bare-boat charters. This is not to say, however, that some contracting parties would not have liked to curtail bare-boat charters. ${ }^{168}$ In light

161 Annex 13 to GC Doc. 99/4. A previous version was included in Annex 12. Both were presented by France on behalf of St Pierre and Miquelon, which has a strong interest in chartering due to difficulties in fishing its quotas with flag vessels.

162 GC Doc. $99 / 4$, section 9.

163 GC Doc. $99 / 9$, para. 4.10.

164 The proposals are included as Annexes 6 and 7 to FC Doc. 99/15. The updated NAFO Conservation and Enforcement Measures (NAFO/FC Doc. 00/1) are available at www.nafo.ca.

165 FC Doc. 99/15, para. 3.29.

166 See Rule 2 of the Rules of Procedure for the Fisheries Commission, available at www.nafo.ca.

167 A more restrictive notification requirement was nevertheless imposed (see Part III.D. 1(b)). See also the discussion in STACTIC, FC Doc. 99/15, Part II, section 8. The Part III.D.2.B that is discussed seems in the end to have been removed from the text.

${ }^{168}$ See the observations by Canada and Japan on the "use it or lose it" approach in section 9 and Annex 3 to GC Doc. 99/4. 
of the applicable rules of international law and the reality in ownership and registration, their hopes were perhaps a little too optimistic.

ICCAT

At the 11th Special Meeting of ICCAT in 1998, the Working Group on Allocation Criteria (ICCAT Allocation Working Group) was established pursuant to ICCAT Resolution 98-15. ${ }^{169}$ The main reason for its instigation was the widespread dissatisfaction with current allocation practice within ICCAT, which is mainly based on historical catch. In comparison with NAFO, the need to address this issue was felt as even more pressing. Its First Meeting was held between 31 May and 2 June 1999 and the Second Meeting took place in April 2000. The report of the latter was not yet adopted at the time of writing. Moreover, as the First Meeting did not lead to the adoption of any instruments, essentially not much more can be done here than to single out certain aspects of the discussion. It is expected that the annual ICCAT meeting in 2000 will decide to convene a Third Meeting of the Working Group.

The focus of the Working Group's terms of reference was: "[t]o analyse and consider recommending criteria for quota allocation, including allocation matters affecting current Contracting Parties, new Contracting Parties and non-contracting parties, entities or fishing entities, to be adopted by ICCAT" and "[t]o analyse and consider other relevant matters related to this objective". This mandate, quite unlike the terms of reference of the NAFO Allocation Working Group, from the outset is clear that it will also specifically address the issue of non-participants. This is hardly surprising in light of ICCAT's cooperative and progressive approach towards non-contracting parties. ${ }^{170}$ In addition, Article XIV(2) ICCAT Convention in principle gives every state the right to become a contracting party. ${ }^{171}$ The terms of reference do not mention the concept of "real interest", but in the discussions during the First Meeting this surfaced frequently and, at a late stage of the meeting, was among the main issues that was identified as in need of further discussion. ${ }^{172}$

The way in which the concept of "real interest" is referred to is quite striking. Namibia is the only one from the many observers ${ }^{173}$ who invokes the concept of "real interest" to bolster its own position. ${ }^{174}$ Merely having observer status is not

169 Entitled "To Establish a Working Group on Allocation Criteria" (text available at www.iccat.es).

${ }^{170}$ See, inter alia, ICCAT Resolutions 94-6 and 97-17.

171 International Convention for the Conservation of Atlantic Tunas, Rio de Janeiro, 14 May 1966, in force 21 March 1969, www.iccat.es. See also the 1984 Protocol (Paris, 10 July 1984, in force 13 November 1997, www.iccat.es), which allowed the EC to become a contracting party.

172 As summarised by the Chairman, Report, para. 6.79 .

173 In addition to Taiwan, the following states and entities were observers: Belize, Colombia, the Faroe Islands, Guatemala, Iceland, Malta, Mexico, Namibia, Norway, the Philippines, and Turkey.

174 See para. 6.70 and its Closing Statement. 
perceived as problematic; something which contrasts sharply with the MHLC process. In view of ICCAT's approach to non-contracting parties and the decision to invite observers to the ICCAT Allocation Working Group, fear of being denied participation in ICCAT would indeed seem to be unnecessary.

The EC consistently emphasises the relevance of the concept of "real interest" in the discussions, and in its proposal on "Elements of Allocation Criteria" it assumes a central role. ${ }^{175}$ According to the EC, "[a]ccess to quotas should be reserved to those Parties qualified as having a real interest in the fishery. This real interest should include, inter alia, the capacity to implement conservation measures, and should exclude quota trading and vessel chartering."176 The element of capacity is also pursued by the United States in its proposal on "Allocation Criteria". 177 While no reference is made to the concept of "real interest", and restrictions on participation are not envisaged either, "[n]ew members must be able to demonstrate an ability to ensure compliance with ICCAT recommendations (including monitoring and reporting) before any allocation can be considered". This suggests that both states strive for something similar to the notion of "qualifying criteria" developed in the NAFO Allocation Working Group.

Particularly noteworthy is the EC's position on quota trading and vessel chartering, which diverges substantially from the output of the NAFO Allocation Working Group. The delegation of Brazil agreed that quota trading was an "inappropriate practice" but emphasised that many states are dependent on vessel chartering to develop their fisheries. ${ }^{178}$ In this latter position it was supported by other delegations. ${ }^{179}$ Consequently, the Chairman included quota trading and vessel chartering as issues to be further discussed. A consultation between the delegations of the United States and the EC during the meeting of the Working Group did not result in agreement on these two issues. The delegation of the United States nevertheless "suggested that, depending on how

${ }^{175}$ See paras 6.6, 6.18 and 6.57 and Appendix 4 to the 1999 Report of the ICCAT Allocation Working Group.

${ }^{176}$ Appendix 4 to the 1999 Report of the ICCAT Allocation Working Group. In para. 6.57, the EC took the position that the concept of "real interest" is "relative to the existing level of effort and co-operation" and that "the State must be able to manage its fisheries and to use the allocated resource".

177 Appendix 5 to the Report.

${ }^{178}$ Para. 6.63 of the Report. See also para. 4 of the Brazilian proposal "On Elements for Allocation Criteria" (Appendix 6 to the Report), that was supported by 17 other states and entities, which considers that the mechanism for catch allocation "should exclude practices leading to nonutilization of quotas by the members to which the quota has been assigned, such as quota trading".

${ }^{179}$ See the comments by China in para. 6.67 , by Namibia in para. 6.70, by CARICOM (Caribbean Community) in para. 6.74 and by Iceland in para. 6.75 of the Report. 
the term is defined, vessel chartering could be another relevant criterion to consider". 180

More generally, the discussion on allocation criteria reflects, just as in the NAFO Allocation Working Group, a concern that this type of discussion could have a detrimental impact on the stability of an RFMM. On the other hand, wider recognition seemed to exist that such a discussion is in fact necessary and critical to the future of ICCAT. The positions taken by, for instance, the EC, Japan and the United States, appear to reflect more willingness to accommodate non-participants, inter alia, by offering them "co-operation quotas". ${ }^{181}$ The Opening Statement by the EC is also characteristic where it identifies the objective of striking "a reasonable balance between the interests of countries traditionally involved in tuna fisheries and the legitimate aspirations of other countries to develop their fishing activity". Moreover, unlike within NAFO, no broad support exists that benefits from recovering stocks should accrue to existing participants as it is recognised that they are responsible or share responsibility for the depleted stock status. ${ }^{182}$

Another notable result of the meeting is that the EC and the United States agreed that the objective of "ensuring equitable fishing opportunities for all members" should appear in the chapeau of an agreed document on allocation criteria. ${ }^{183}$ Not without justification, the EC observed in its Closing Statement that the results and the degree of progress achieved during the First Meeting of the ICCAT Allocation Working Group "are positive in itself and notable in comparison to the parallel work carried out within" NAFO and the MHLC process. This optimism is of course commendable, although one should not lose sight of the very serious concerns of the many states parties and non-parties that are dissatisfied with the current allocation practice. To them this review was long overdue.

As the Report of the Second Meeting had not yet been adopted at the time of writing, and only parts of it were available to the author, only some general remarks can be made. First, wider support for the role of compliance, both as a qualifying criterion and as allocation criterion, seemed to crystallise. Support for this was voiced by several developed states, namely, Canada, the EC, Japan, South Korea and the United States. Secondly, all participants agreed that quota trading should be prohibited. This led the EC to observe that a new entrant would not be given an allocation simply for trading purposes. In that context, the EC had also suggested that real interest should be reflected in effective fishing capacity or the capacity to develop a fleet. This did not appear to secure much

${ }^{180}$ Para. 6.87 of the Report.

181 See the proposal by the EC, in Appendix 4 to the Report, the Opening Statements by the EC and Japan, and para. 6.56 of the Report.

182 See, for example, the comments by Turkey in para. 6.71. Responsibility for over-exploitation is regarded as a relevant allocation criterion (see para. 1(j) of the Brazilian proposal in Appendix 6 and para. 3(i) of the United States proposal in Appendix 5). 
support. The related issue of vessel chartering seemed to develop to something similar to that agreed within NAFO.

\section{$N E A F C$}

The Working Group on the Future of the NEAFC first met in March 1997. Its objective was to review the NEAFC Convention, ${ }^{184}$ inter alia, in the light of the 1995 Fish Stocks Agreement. Among the many issues under consideration were the concept of real interest and new participants but not vessel chartering. The discussion was resumed during the Second Session in July 1997, and at the 16th Annual NEAFC Meeting (1997) it was decided that the Working Group would continue its work. In fact, the Russian Federation specifically suggested that the Working Group should focus on amendments to the NEAFC Convention. ${ }^{185}$ As broad support for such an undertaking was apparently lacking, discussion on this issue was not revisited and has so far not led to a concrete outcome. ${ }^{186}$ Instead, the emphasis was placed on developing a NEAFC "Scheme to Promote Compliance by Non-Contracting Parties with Recommendations Established by NEAFC" and a NEAFC Control and Enforcement Scheme. ${ }^{187}$ Preparatory work has in part been carried out in the above-mentioned Working Group during its two sessions in 1998. No further sessions have been held since.

A detailed analysis of the various views expressed during the first two sessions would take up too much space. Suffice it to say that a measure of similarity exists with the discussion within NAFO. The concept of "real interest" was widely regarded as relevant but a common definition could not be agreed on. ${ }^{188}$ In general, the EC, Poland and the Russian Federation appeared to support an open organisation and would also be prepared to offer TAC allocations to new participants. ${ }^{189}$ Conversely, Denmark (on behalf of the Faroe Islands and Greenland), Iceland and Norway seemed to take a more restrictive position by emphasising that, although new participants could become members of NEAFC,

183 Para. 6.87 of the Report.

184 Convention on Future Multilateral Co-operation in the North-East Atlantic Fisheries, 18 November 1980, in force 17 March 1982; www.neafc.org.

185 Report, p. 16, para. 64. The Opening Statement of the Russian Federation at the 18th Annual NEAFC Meeting (1999) reiterates this suggestion and specifically mentions the allocation issue (Annex A to the Reporl).

186 In the Session of June 1998, the Working Group recommended that these issues should be discussed at annual meetings (see para. 28 of the Report).

187 See Annex F to the Report; and www.neafc.org.

188 See paras 5.6 and 8.4 of the Report of the First Session; and paras 6.6-6.15 of the Report of the Second Session. It is interesting to note that Norway argued that fishing in itself is insufficient to demonstrate a real interest and that a linkage should be made to aspects such as performance (see para. 4.7 of the Report of the First Session; and para. 6.7 of the Report of the Second Session).

189 See paras 4.14, 4.16 and 4.19 of the Report of the First Session; and paras 6.9 and $6.13-6.14$ of the Report of the Second Session. 
this would not necessarily imply TAC allocations. ${ }^{190}$ Article 20(4) of the NEAFC Convention emerged prominently in this discussion. It currently provides that accession to the NEAFC Convention requires the explicit approval of threequarters of all the contracting parties. The need to amend this provision was argued most strongly by the EC, although wider support existed that the provision was probably questionable in light of Article 8(3) of the 1995 Fish Stocks Agreement. As is clear from the discussion above, the existence of diverging positions would not preclude amendment.

An important part of the discussion centred around the Icelandic proposal that NEAFC should establish a management committee "for each stock with which NEAFC is involved, so that only states with a real interest in a stock could take part in discussions on its management". ${ }^{191}$ In the end, this proposal was unable to secure sufficient support.

Notwithstanding the absence of a relevant concrete outcome of the discussion in the Working Group, it should be noted that, in developing regulatory efforts in NEAFC, a preference exists for uniformity with similar efforts within NAFO. Whether this will also happen with respect to the issue of new participants and allocation is difficult to say. At any rate, the Chairman of the Working Group was quite aware of the risks of precedents and noted that "it might be more realistic to await, in the context of upcoming dispute settlement procedures, relevant case law". ${ }^{192}$

\section{Conclusions}

The analysis of the state practice above reveals considerable differences in approach towards the concept of "real interest". Both the MHLC process and the NEAFC Convention take a restrictive attitude towards the issue of participation, ${ }^{193}$ whereas the initial impressions of the other three fora are those of "relatively open" organisations. Arguably, the fact that Article 8(5) of the 1995 Fish Stocks Agreement, which deals with negotiations to establish RFMMs, does not explicitly refer to the concept of "real interest" is not necessarily a sufficient excuse for this restrictive attitude in the MHLC process.

Even though the other three fora are characterised as "relatively open", important differences exist. While adherence by new participants to the SEAFO Convention is expected to be possible only for fishing states, the NAFO Convention does not include any substantive requirements but instead reserves membership of its Fisheries Commission to states already fishing and those

${ }^{190}$ See paras 4.7 and 4.14 of the Report of the First Session; and paras 6.7-6.8 of the Report of the Second Session.

${ }^{191}$ Para. 3.2 of the Report of the First Session. See also para. 4.11 of the same report; and para. 7.7 of the Report of the Second Session.

${ }_{192}^{192}$ Para. 8.4 of the Report of the First Session.

${ }^{193} \mathrm{Hey}$, note 9 above at p. 106 also mentions that, under the IATTC Convention (Inter-American Tropical Tuna Convention, 31 May 1949, in force 3 March 1950, 80 UNTS 4), contracting parties have a wide discretion in accepting or denying requests for participation (Art. V(3)). 
expected to be fishing within a certain time. The ICCAT Convention does not contain a relevant substantive requirement for adherence at all. Implicitly, these instruments thereby give effective content to the concept of "real interest".

Only NAFO and ICCAT address the allocation discussion comprehensively. In due time, the other three fora are expected to undertake the same type of discussions. In both NAFO and ICCAT there seems to be some support for linking allocations for new participants to meeting certain "qualifying criteria". These criteria define minimum standards for the performance or capacity of a state in the conservation and management of living marine resources. As argued above, this amounts to an implicit application of the concept of real interest. Within ICCAT there even seems to be broad support to treat performance of existing participants, e.g. compliance with ICCAT's conservation and management recommendations, as an allocation criterion. ${ }^{194}$ While it cannot be ruled out that ICCAT will develop an approach on vessel chartering that deviates from the NAFO approach, this is not very likely. ${ }^{195}$ Finally, within ICCAT there seems to be preparedness for broader sharing of TAC allocations with new participants in comparison with NAFO. The contrast with the MHLC process hardly needs further comment.

The differences identified in the preceding paragraphs logically ask for explanations. It is submitted that these explanations lie predominantly in the different characteristics of RFMMs or negotiation processes to establish RFMMs. These include the often interrelated factors such as the characteristics of the regulated fisheries, the spatial scope of the regulatory area, and the number and type of states engaged in fishing, both as participants and nonparticipants, or those that wish to start fishing, namely, new entrants. Each RFMM will eventually have to strike a balance between the various interests involved. As has become clear in this article, little support or justification in fact exists for merely taking account of the respective interests of coastal and flag states. A pressing need exists also to balance the interests of existing participants in RFMMs, who have traditionally been involved in a fishery, with nonparticipants, including new entrants. In addition, account will have to be taken of the interest of the international community in the sustainable use and conservation of living marine resources and in biological diversity. One of the main objectives for this balance would be that of ensuring equitable fishing opportunities for all. What is ultimately determined to be equitable depends to a large extent on the context in which the balance of interests is struck and not so much on the availability of legal bases for the respective interests, as

${ }^{194}$ See para. 3(c) of the United States proposal in Appendix 5, and para. 1(d) of the Brazilian proposal in Appendix 6. Also, the "qualifying criteria" developed in the NAFO Allocation Working Group include "Contracting Parties "in good standing".

${ }^{195}$ This appears to be supported during the Second Meeting of the ICCAT Allocation Working Group. The NAFO approach on vessel chartering also seems to have support in the SEAFO process. 
international law does not suffer from significant omissions in that respect. A dominant role would seem to be reserved for extra-legal elements, for example the negotiation power inherent in the fact that high seas fishing in the regulatory area of the future WCPFO is not economically viable without concurrent access to coastal state maritime zones.

To strike a balance which takes all these interests into account is an extremely complex task. A risk always exists that non-participants have insufficient incentives to join an RFMM or, on the other hand, that existing participants feel compelled to withdraw from it. In trying to balance the interests of new and existing participants, a serious risk exists that minimal margins for negotiation will ultimately threaten the interest of the international community and lead to a further depletion of living marine resources and loss of biological diversity.

\section{RFMMs and Dispute Settlement}

Dispute settlement procedures are often regarded as essential for bolstering the effectiveness of an RFMM. ${ }^{196}$ It is inherent in their sovereignty that states cannot be forced to become involved in procedures that are instituted against their will and to face certain types of outcomes of these procedures. In light of this wide discretion, the fact that states were able to agree on Part XV of the LOS Convention was seen as an enormous accomplishment. Part XV is generally regarded as a comprehensive or umbrella dispute settlement procedure where, apart from certain exceptions, compulsory third party dispute settlement entailing binding decisions is the general rule. Whereas the Order by the ITLOS in the Southern Bluefin Tuna (Provisional Measures) cases ${ }^{197}$ strengthens this characterisation, the Award of the Arbitral Tribunal in the Southern Bluefin Tuna case ${ }^{198}$ effectively contends quite the opposite. As the Arbitral Tribunal acknowledges that the issues which it had to address were "of singular complexity and significance", careful analysis is called for. Unfortunately, limited space allows only a brief discussion.

The first main issue in these proceedings was that of the substantive and procedural parallelism between the LOS Convention as the global "umbrella" on the one hand and regional instruments on the other. Australia and New Zealand instituted a procedure entailing a binding decision under section 2 of Part XV of the LOS Convention against Japan, on account of the fact that all three states were parties to the LOS Convention. The applicants nevertheless argued that, even though the dispute had arisen within the framework of the Convention for the Conservation of Southern Bluefin Tuna (CCSBT Convention), ${ }^{199}$ the

\footnotetext{
196 The use of "procedure" is intended to include the common situation where various forms of dispute settlement can be opted for.

197 Note 27 above.

198 Note 37 above.

199 Note 29 above.
} 
dispute's characteristics were such that it also concerned the "interpretation or application" of the LOS Convention. Not surprisingly, Japan held that the dispute only concerned the "interpretation or implementation" of the CCSBT Convention. Both the ITLOS and the Arbitral Tribunal agreed with Australia and New Zealand on this point. As the ITLOS merely had to find prima facie jurisdiction, its observations in paragraphs $48-52$ of its Order are quite succinct. In the more thorough assessment that was expected of the Arbitral Tribunal, it held that:

"it is a commonplace of international law and State practice for more than one treaty to bear upon a particular dispute. There is no reason why a given act of a State may not violate its obligations under more than one treaty. There is frequently a parallelism of treaties, both in their substantive content and in their provisions for settlement of disputes arising thereunder." 200

In the particular circumstances of the case, the Arbitral Tribunal concluded that the dispute "while centred in the [CCSBT Convention], also arises under the [LOS Convention]". ${ }^{201}$

The second main issue in both proceedings concerned the relationship between dispute settlement procedures under regional instruments and those under Part $\mathrm{XV}$ of the LOS Convention. Article 16 of the CCSBT Convention provides that disputes "concerning the interpretation or implementation" of the Convention shall be resolved by the parties involved by any peaceful means of their choice. ${ }^{202}$ As all parties to the dispute have to agree not only on the appropriate procedure but also on whether or not a procedure should be started in the first place, this is consensual rather than compulsory dispute settlement. In contrast, the striking feature of Part XV of the LOS Convention is that Section 2 provides for compulsory dispute settlement entailing binding decisions where parties to a dispute are unable to reach a settlement under section 1 and the general (automatic) limitations and optional exceptions under Section 3 do not apply. Crucial in both cases were Articles 281(1) and 282 of the LOS Convention, both laid down among the "General Provisions" in Section 1. Article 281(1), entitled "Procedure where no settlement has been reached by the parties", provides:

"If the States Parties which are parties to a dispute concerning the interpretation or application of this Convention have agreed to seek settlement of the dispute by a peaceful means of their own choice, the procedures provided for in this Part apply only where no settlement has been reached by recourse to such means and the agreement between the parties does not exclude any further procedure."

200 Award, p. 91, para. 52.

${ }^{201}$ Ibid., p. 93, para. 52. See also note 218 below. 
And Article 282, entitled "Obligations under general, regional or bilateral agreements", provides:

"If the States Parties which are parties to a dispute concerning the interpretation or application of this Convention have agreed, through a general, regional or bilateral agreement or otherwise, that such a dispute shall, at the request of any party to the dispute, be submitted to a procedure that entails a binding decision, that procedure shall apply in lieu of the procedures provided for in this Part, unless the parties to the dispute otherwise agree."

The Order of the ITLOS and the Award of the Arbitral Tribunal take fundamentally different approaches towards these two provisions. This proved to be of crucial importance for the ITLOS's conclusion that it had prima facie jurisdiction to prescribe provisional measures and the Arbitral Tribunal's conclusion that it lacked jurisdiction to deal with the merits.

The ITLOS deals with these issues in paragraphs 53-62 of its Order. The main conclusion here is that the negotiation efforts of Australia and New Zealand were sufficient in the context of Article 281 and allowed them to invoke a compulsory procedure under section $2 .{ }^{203}$ In addition, the ITLOS considers in paragraph 54:

"that Australia and New Zealand maintain that they are not precluded from having recourse to the arbitral tribunal since the [CCSBT Convention] does not provide for a compulsory dispute settlement procedure entailing a binding decision as required under article 282 of the [LOS Convention]."

The ITLOS continues by concluding that "the fact that the [CCSBT Convention] applies between the parties does not preclude recourse to the procedures in Part $\mathrm{XV}$, section 2 of the [LOS Convention]". ${ }^{204}$ While thus not explicitly ruling on the interpretation of Article 282, it appears to agree, at least for the purpose of establishing prima facie jurisdiction, with the view taken by Australia and New Zealand. Accordingly, Article 282 not only says something explicitly but also implicitly: where regional agreements do not have a compulsory dispute settlement procedure entailing a binding decision, Part $\mathrm{XV}$ of the LOS Convention is in principle applicable.

As already noted, the view of the Arbitral Tribunal is fundamentally different. Even though it agrees that Australia and New Zealand have discharged their obligations on negotiation, the Arbitral Tribunal argues that the requirement incorporated in the last clause of Article 281(1) of the LOS Convention, namely, "the agreement between the parties does not exclude any further procedure", has

\footnotetext{
${ }^{202}$ The Annex to the CCSBT Convention deals with arbitration.

203 See also above.

204 Order, para. 55.
} 
not been met. In its view, it is not decisive that the terms of Article 16 of the CCSBT Convention "do not expressly and in so many words exclude the applicability of any procedures, including the procedures of section 2 of Part XV of [the LOS Convention]". 205 Article 16 of the CCSBT Convention, and in particular the second clause in its paragraph (2), 206 "intends to remove proceedings under that Article from the reach of the compulsory procedures" of the LOS Convention. ${ }^{207}$

The Arbitral Tribunal mentions three considerations in support of its view. First, the fact that Article 16 of the CCSBT Convention was modelled on Article XI of the Antarctic Treaty, 208 which is widely agreed to exclude compulsory jurisdiction. Secondly, Part XV of the LOS Convention "falls significantly short of establishing a truly comprehensive regime of compulsory jurisdiction entailing binding decision" 209 due to the general (automatic) limitations and optional exceptions in its Section 3. Thirdly, that "a significant number of international agreements with maritime elements, entered into after the adoption of [the LOS Convention], exclude with varying degrees of explicitness unilateral reference of a dispute to compulsory adjudicative or arbitral procedures", 210

Faced with the uncertain meaning of the last clause of Article 281(1) of the LOS Convention, 211 the Arbitral Tribunal must have felt compelled to be cautious and conclude that it lacked jurisdiction. It is nevertheless surprising that no attention was given to the relationship between Article 281(1) and Article 282, in particular as Australia and New Zealand relied heavily on the latter provision. ${ }^{212}$

The final observation of the Tribunal is devoted to the impact of the entry into force of the 1995 Fish Stocks Agreement for states parties to it. The Tribunal argues that this will "not only go far towards resolving procedural problems that have come before this Tribunal but, if the Convention ${ }^{213}$ is faithfully and

${ }^{205}$ Award, p. 97, paras 56-57.

206 This reads: "failure to reach agreement on reference to the International Court of Justice or to arbitration shall not absolve parties to the dispute from the responsibility of continuing to seek to resolve it by any of the various peaceful means referred to it in paragraph 1 above."

207 Award, pp. 98-99, para. 57.

208 The Antarctic Treaty, Washington DC, 1 December 1959, in force 23 June 1961, 402 UNTS 71 (1961); www.antdiv.gov.au/treaty.

209 Award, p. 102, para. 62.

210 Ibid., p. 103 , para. 63.

211 The Virginia Commentary does not indicate in what way parties to an agreement should specify how "any further procedure" should be excluded either (see S. Rosenne and L.B. Sohn (volume eds) and M.H. Nordquist (editor-in-chief), United Nations Convention on the Law of the Sea 1982, A Commentary (Dordrecht, Boston, London, Martinus Nijhoff Publishers, 1989), vol. V, pp. 23-24).

212 Nor does the Award address the argument by Australia and New Zealand that states cannot, at the bilateral or regional level, agree to render Part XV of the LOS Convention inoperative (socalled "negative provisions") as this would be "incompatible with the effective execution of the object and purpose of [the LOS Convention]" or "affect the basic principles embodied therein" (Art. 311(3) of the LOS Convention).

213 It is assumed that the 1995 Fish Stocks Agreement is meant here. 
effectively implemented, ameliorate the substantive problems that have divided the Parties". ${ }^{214}$ The Tribunal subsequently repeats the substance of the first two paragraphs of Article 30 of the 1995 Fish Stocks Agreement, which make Part $\mathrm{XV}$ of the LOS Convention mutatis mutandis applicable to disputes concerning the interpretation or application of the 1995 Fish Stocks Agreement or of "a subregional, regional or global fisheries agreement relating to straddling fish stocks or highly migratory fish stocks to which they are parties, including any dispute concerning the conservation and management of such stocks".215 However, in light of the Award it is debatable whether paragraph (2) of Article $30 \mathrm{can}$, on its own account, resolve the identified problems. The Tribunal seems to acknowledge this when it emphasises the importance of the faithful and effective implementation of the 1995 Fish Stocks Agreement. Mutatis mutandis applicability may therefore still lead to the type of assessments in the context of Articles 281 and 282 of the LOS Convention that the Tribunal had to undertake.

An issue which neither the Order nor the Award resolves, is the scope of the exceptions from jurisdiction on account of coastal state sovereignty or sovereign rights under Article 297(3) of the LOS Convention and Article 32 of the 1995 Fish Stocks Agreement. In fact, neither the ITLOS nor the Tribunal was asked to address this controversy and this was not really surprising as the applicants were coastal states. ${ }^{216}$

The Award in the Southern Bluefin Tuna case is of obvious significance not only for existing RFMMs and negotiation processes aimed at establishing RFMMs, ${ }^{217}$ but in fact for all regional instruments under which disputes may

214 Award, p. 110, para. 71.

215 This applies to states partics to the 1995 Fish Stocks Agreement, whether or not they are also parties to the LOS Convention.

${ }^{216}$ On this issue see B. Kwiatkowska, "The Southern Bluefin Tuna (New Zealand v Japan; Australia v Japan) Cases", (2000) 15 International Journal of Marine and Coastal Law 1-36 at 19 and 33-35, who, inter alia, comes to the conclusion that in the merits phase before the Arbitral Tribunal, Japan could be entitled to submit a counterclaim related to the EEZ part of the straddling or highly migratory fish stock. Cf. A.E. Boyle, "Problems of Compulsory Jurisdiction and the Settlement of Disputes Relating to Straddling Fish Stocks", (1999) 14 International Journal of Marine and Coastal Law 125 at 13 and 25. See also T.L. McDorman, "The Dispute Settlement Regime of the Straddling and Highly Migratory Fish Stocks Convention", (1997) 35 Canadian Yearbook of International Law 57-79 at 65-66. In fact, Crawford, Counsel for Australia in the Southern Bluefin Tuna case, admits that Art. 297(3) "does not create any jurisdictional barrier to this Tribunal taking into account [Australian and New Zealand] practices in fishing SBT in the EEZs, to the extent that this may be relevant in considering this case" (Oral Hearings, Second Round Presentation of Australia and New Zealand, 11 May 2000, vol. IV, p. 83 (see note 37 above)).

217 The SEAFO Draft Convention (Sixth Meeting) provides that any party to a dispute can resort to the dispute settlement mechanism under Part XV of the LOS Convention or, where the dispute concerns one or more straddling stocks, Part VIII of the 1995 Fish Stocks Agreement. This applies "whether or not the Parties to the dispute are also Parties to these instruments" (Art. 23, in particular para. (4)). Art. 31 of the WCPFO Draft Convention (Sixth Session) provides: "The provisions relating to the settlement of disputes set out in Part VIII of the [1995 Fish Stocks Agreement] apply, mutatis mutandis, to any dispute between members of the Commission concerning the interpretation and application of this Convention, whether or not 
arise that also concern the interpretation and application of the LOS Convention. While the ITLOS Order suggested that dispute settlement procedures established by RFMMs that do not conform to the requirements as laid down in Article 282 of the LOS Convention can be circumvented, the Award of the Arbitral Tribunal firmly confirms the discretion of states at the regional level. ${ }^{218}$ In the view of Australia and New Zealand, Part XV of the LOS Convention has become "a paper umbrella which dissolves in the rain". ${ }^{219}$ Article 30(2) of the 1995 Fish Stocks Agreement does not necessarily bring an end to this discretion.

\section{Conclusions}

While the redistribution of rights over marine living resources brought about by the LOS Convention was certainly favourable to coastal states, it did not affect the need for inter-state co-operation in the management of transboundary stocks. Apart from the fact that aligning management is common sense, both conventional law and customary international law require states to co-operate in relation to most, if not all, transboundary stocks. The advent of the precautionary approach reinforces this by requiring states to do more at an earlier stage.

The current body of international law on fisheries management of transboundary stocks reaffirms time and again that states are obliged to attain the strongly interrelated objectives of sustainable management and inter-state cooperation. While the relevant international instruments reflect a certain preference for fisheries management through regional fisheries management mechanisms (RFMMs), little guidance is given on specific aspects of cooperation. The particular circumstances of each case will therefore determine, inter alia, the spatial limits of the RFMM's regulatory area and which states have rights or obligations to participate. The considerable margin of discretion which states retain bears witness to the many complexities in not only fisheries management but also more generally in inter-state co-operation.

By definition, this margin of discretion has its limits, as is reflected in the

cont.

they are also Parties to the [1995 Fish Stocks Agreement]." Within the NAFO, a Working Group on Dispute Settlement Procedures is currently investigating ways in which the NAFO Convention, which currently lacks procedures for dispute settlement, can include such procedures (see c.g. the Working Group's 1999 Report, GC Doc. 99/2).

218 In para. 64 of the Award, the Arbitral Tribunal nevertheless recognises that "there might be instances in which the conduct of a State Party to [the LOS Convention] and to a fisheries treaty implementing it would be so egregious, and risk consequences of such gravity, that a Tribunal might find that the obligations of [the LOS Convention] provide a basis for jurisdiction". This might for instance occur in relation to the good faith obligation in Art. 300 of the LOS Convention. Certain disputes will of course be confined to the regional level, for example when

it concerns the functions of institutional bodies of RFMMs.

Award, p. 77, para. 41(k). 
unqualified rejection of unilateralism in the recent Order of the ITLOS in the Southern Bluefin Tuna (Provisional Measures) cases. However, the Award by the Arbitral Tribunal in the Southern Bluefin Tuna case amounts to a reversal of the ITLOS Order by acknowledging the wide margin of discretion that states have in agreeing on dispute settlement procedures at the regional level.

One of the main challenges to the management of transboundary stocks continues to be the balancing of different interests. Traditionally, this balance was struck primarily between coastal and flag state interests while a mere subsidiary role was accorded to the international community's interest in the management and conservation of marine living resources and in biological diversity. It is expected that the concept of "real interest", as incorporated in Article 8(3) of the 1995 Fish Stocks Agreement, will affect this balance. The lack of a generally accepted definition for the concept does not necessarily prevent this from occurring. It has nevertheless been argued that the negotiators of the 1995 Fish Stocks Agreement included the concept primarily to limit participation in RFMMs to states with an intention to fish. This was meant to avoid a situation such as currently exists under the IWC Convention where a large majority opposes exploitation. Judging by the way in which RFMMs and negotiation processes aimed at establishing RFMMs struggle to give the concept effective content, however, this rather limited interpretation is not widely adhered to.

The concept of "real interest" is not to be linked to "piercing the flag state veil" and thereby lead to entitlements based on foreign involvement in the flag state's fishing industry. This should certainly not be explained as a failure to appreciate the growing role of multinationals in global fishing due to, inter alia, flexible vessel registration policies and increased use of management through individually transferable quotas (ITQs). On the contrary, these developments often constitute the core of the problems experienced by many RFMMs. While addressing these problems, appropriate account should be taken of their causes but obviously also of the applicable limits set by international law.

A logical presumption would seem to be that the concept of "real interest" has a wider purpose. This could be to reserve high seas fishing to a certain group or type of states. In light of the fact that, under general international law, all states have a qualified right for their nationals to engage in high seas fishing, convincing arguments for this perceived wider purpose are nevertheless wanting. Developments in RFMMs and negotiation processes aimed at establishing RFMMs generally confirm that the concept of "real interest" is not used to limit participation in RFMMs per se. Events such as those in the MHLC process are thus more an exception than the general rule. A more likely scenario is that the issue of participation in RFMMs will be resolved through TAC allocation. At the same time, RFMMs may certainly be tempted to remain or become "exclusive clubs" by means of allocating the TAC.

This does not mean that the concept of "real interest" is irrelevant. Apart from acting as a focal point in assessing the legitimacy of new participants' 
aspirations, the concept might also assist in countering the detrimental effects of reflagging and flags of convenience. A certain measure of flag state responsibility or performance can be ensured by insisting that flag states maintain a genuine link with ships flying their flag. In the $M / V$ Saiga case, the ITLOS confirmed that this requires flag states to exercise effective jurisdiction and control over their ships. RFMMs could therefore opt to draft their terms and conditions for participation in a way that would guarantee a certain minimum level of flag state performance. This would give effective content to the concept of "real interest". An alternative would be to define a similar standard as a "qualifying criterion" for TAC allocations. In a strict and/or formal sense this would not have an impact on the issue of participation and, consequently, could not be regarded as an explicit application of the concept of "real interest". However, as it could imply being barred from engaging in fishing, it would amount to an implicit application. Both the explicit and the implicit application effectively link the concept of "real interest" to the further regulation of (high seas) fishing. Whereas this would in principle be a commendable regulatory objective, appropriate account should be taken of the rights and interests of developing states. As is reflected in current state practice, this would for example imply that vessel chartering or bare-boat chartering cannot a priori be excluded.

One way or another, the concept of "real interest" is expected to influence the continuous readjustment of the balance of interests in global marine capture fisheries due to its strong association with the conflicting interests of participants and non-participants (including new entrants) in RFMMs. These conflicting interests will somehow have to be accommodated to ensure equitable fishing opportunities for all. As world fisheries are currently in a deplorable state, this is obviously not going to be an easy task. This calls for increased awareness of, and respect for, the ultimately superior interest of the international community in the sustainable conservation and management of living marine resources and in biological diversity. 